\title{
ポンプ吸込水槽に発生する水中渦の流れ構造
}

\author{
山出 吉伸 ${ }^{* 1}$, 加藤 千幸 ${ }^{* 2}$, 長原 孝英*3, 松井 純 ${ }^{* 4}$
}

\section{Flow structure of a submerged vortex in a pump sump}

\author{
Yoshinobu YAMADE ${ }^{* 1}$, Chisachi KATO ${ }^{* 2}$, Takahide NAGAHARA ${ }^{* 3}$ and Jun MATSUI ${ }^{* 4}$ \\ ${ }^{* 1}$ Mizuho Information \& Research Institute, Inc. \\ 2-3 Kanda-Nishiki-cho, Chiyoda-ku, Tokyo 101-8443, Japan \\ ${ }^{* 2}$ Institute of Industrial Science, The University of Tokyo \\ 4-6-1 Komaba, Meguro-ku, Tokyo 153-8505, Japan \\ ${ }^{* 3}$ Industrial Products Company, Hitachi, Ltd. \\ 603 Kandatsu-cho, Tsuchiura-shi, Ibaraki 300-0013, Japan \\ ${ }^{* 4}$ Faculty of Engineering, Yokohama National University \\ 79-2 Tokiwadai, Hodogaya-ku, Yokohama 240-8501, Japan
}

Received: 21 July 2019; Revised: 8 September 2019; Accepted: 30 September 2019

\begin{abstract}
The flow structures of a submerged vortex that appears in a model pump sump have been fully clarified by performing large eddy simulation (LES) of a model vortex in a simplified computational model. The computational model had a sufficiently fine grid that could resolve the vortex core. The model sump is composed of a 2,500 mm-long water channel of rectangular cross section with a width of $300 \mathrm{~mm}$ and a water height of $150 \mathrm{~mm}$ and a vertical suction pipe with a $100 \mathrm{~mm}$ diameter installed at its downstream end. Our previous large eddy simulations (LES), which used approximately 2 billion grids and were applied to the whole pump sump, has fully clarified the origin and formation mechanism of a submerged vortex and an air-entrained vortex. In these computations, however, the static pressure in the vortex core decreased by only $5 \mathrm{kPa}$ at a channel velocity of $0.37 \mathrm{~m} / \mathrm{s}$. The decrease in the static pressure was far smaller than the one for which one can expect initiation of cavitation in the vortex core. In the corresponding experiment, however, appearance of a submerged vortex was confirmed by the occurrence of cavitation in the vortex core. Therefore, the decrease in the static pressure is most likely to be underpredicted in our previous LES. Insufficient grid resolution was assumed to be one of the reasons for this underprediction. In the present study, LES with a sufficiently fine grid was applied to a simplified computational model that represents the stretch of a submerged vortex under a constant acceleration of the vertical velocity. Vertical and tangential velocities obtained by averaging those profiles of a submerged vortex computed in the previous LES were prescribed at the bottom wall of the computational domain as the inflow boundary conditions. In the present LES, the static pressure has decreased by more than $100 \mathrm{kPa}$. In addition, parametric studies with different initial swirl numbers varied from 0.08 to 10.9 have fully clarified the behavior of a submerged vortex. It is found that a strong submerged vortex appears only at a relatively small range of the swirl-number from 0.8 to 2 .
\end{abstract}

Keywords : Pump sump, Submerged vortices, Large eddy simulation, Vortex core, Strech of a vortex, Swirl number

\section{1. 緒言}

ポンプ吸込水槽に発生する水中渦（submerged vortices）や空気吸込渦（air-entrained vortices），本論文ではこれら の渦をまとめて吸込渦（suction vortices）と称する，はポンプシステムの騒音・振動や損傷の原因となることがあ る.このため, ポンプ吸込水槽の設計の段階で吸込渦発生の条件を把握しておく必要がある. 現状, 吸込渦の発 生の有無は基本的には模型実験による可視化で評価しているが，昨今の計算機の発達により，数值計算により吸

No.19-00294 [DOI:10.1299/transjsme.19-00294], J-STAGE Advance Publication date : 8 October, 2019

*1 正員, みずほ情報総研（株）サイエンスソリューション部（†101-8443 東京都千代田区神田錦町 2-3）

$*_{2}$ 正員，フェロー，東京大学 生産技術研究所（†153-8505 東京都目黒区駒場 4-6-1）

*3 正員, (株) 日立インダストリアルプロダクツ（テ300-0013 茨城県土浦市神立町 603）

*4 正員, 横浜国立大学 大学院工学研究院（二240-8501 神奈川県横浜市保土ケ谷区常盤台 79-2)

E-mail of corresponding author: yoshinobu.yamade@mizuho-ir.co.jp 
込渦の発生の有無を予測する技術の実用化に期待が集まっている。これまでの研究では，主として時間平均ベー スの計算手法が吸込渦の発生の有無の予測に適用されてきた。これらの研究では，ポテンシャル流れ解析あるい は Reynolds Averaged Navier-Stokes Simulation（RANS）により，水槽内部の定常流れを計算することにより，吸込 渦発生の有無を判断する. Ansar らは水槽内の速度場をレーザドップラー流速計により測定し（Ansar and Nakato, 2001), ポテンシャル流れ解析の結果と比較することにより, 水槽内部のおおまかな流れ構造はポテンシャル流れ 解析により予測できることを示している (Ansar et al., 2002). Constantinescu らは水槽内部流れの解析に 2 方程式 型の複数の RANS モデルを適用し, その予測精度を調査している (Constantinescu and Patel, 2000). Okamura らは, 流入流量および水面高さの二つの条件を広範囲に変更した模型水槽実験を実施し, 吸込渦が発生する条件を調查 寸るとともに, RANS ベースの複数の流体解析ソフトウエアによるベンチマークテストを実施し, その予測精度 を検証している (Okamura et al., 2007)。このような時間平均ベースの計算手法は比較的小規模な計算格子により 水槽内部のおおまかな流れ構造を捉えることができるため, 吸込渦発生の有無を判断するためのツールとして, ポンプ吸込水槽の設計において一定の役割を担っている. しかしながら, 時間平均ベースの計算手法では吸込渦 の発生・消滅を含む非定常現象の再現は不可能である.

筆者らは, Okamura らが上記のベンチマークテストに用いたモデル水槽の内部流れを対象に, 最大格子数 20 億, 解像度 $225 \mu \mathrm{m}$ の計算格子を用いて，16 秒間（チャネル長さおよび平均主流速度で規格化した無次元時間で約 60 の間）の LES 解析を実施し, 水中渦や空気吸込渦の起源や発生メカニズムを明らかにし, 前報にて報告した（山 出他，2019）。上記の LES 解析により，水中渦の起源は水槽壁面の境界層の平均的な速度勾配であることなどが 示されたが, LES 解析により再現された水中渦の渦コアの静圧は最大でも大気圧の 5\%（5kPa）程度しか低下し なかった。一方，模型水槽実験で確認される水中渦にはキャビテーションにより気相が発生しているが，大気圧 の $5 \%$ 程度の静圧降下ではキャビテーションによる気相の発生を説明できない. 上記の LES 解析において水中渦 の静圧があまり下がらなかった原因の一つとして格子解像度の不足が考えられる. そこで, 本論文では一つの水 中渦を対象として, 渦コアを解像できるような十分に細かい計算格子を用いて LES 解析を実施し, 水中渦のコア の半径, 軸方向流速分布・周方向流速分布, 静圧分布, および，これらの時間変動に関して詳細に調查した結果 を報告する. また，初期（流入）条件として与えた旋回の強さが水中渦の成長に与える影響に関しても調査した 結果を報告する。

\section{2. ポンプ吸込水槽}

本研究の解析対象は Okamura らが実施したベンチマークテスト（Okamura et al., 2007）で扱ったモデル水槽に 発生する吸込渦である. Okamura らは流入流量および氷面高さを変更し, 吸込渦の発生条件を調查するとともに, 数值解析による予測精度を検証した. 本研究では流入速度 $0.37 \mathrm{~m} / \mathrm{s}$ ，水面高さ $150 \mathrm{~mm}$ （水槽底面からベルマウス 入口までの距離 $100 \mathrm{~mm}$ ，ベルマウス入口から水面までの距離 $50 \mathrm{~mm}$ ）の条件における水槽内の流孔を LES によ り解析し, 解析された流れを詳細に分析した. Okamura らの実験ではこの条件において水中渦および空気吸込渦 の両方が発生することが確認されている.

\section{3. 数値計算手法}

水槽内部流れの解析には in-house コードである FrontFlow/blue (FFB)（Kato et al., 2003, 2005）を用いた. FFB は 乱流現象を高精度に予測することができる LES をべースとする有限要素法流れ解析コードである. 本コードは空 間フィルタ操作を施された速度 $u_{i}$ および静圧 $p$ に対する非圧縮性流体の Navier-Stokes 方程式 (1) を連続の式と ともに解く.

$$
\frac{\partial u_{\mathrm{i}}}{\partial t}+u_{\mathrm{j}} \frac{\partial u_{\mathrm{i}}}{\partial x_{\mathrm{j}}}=-\frac{1}{\rho} \frac{\partial p}{\partial x_{\mathrm{i}}}+\frac{\partial}{\partial x_{\mathrm{j}}}\left\{\left(v+v_{\mathrm{SGS}}\right)\left(\frac{\partial u_{\mathrm{i}}}{\partial x_{\mathrm{j}}}+\frac{\partial u_{\mathrm{j}}}{\partial x_{\mathrm{i}}}\right)\right\}
$$

ここで, $v_{\mathrm{SGS}}$ は渦動粘性係数であり, 式（2）で計算される. 


$$
v_{\mathrm{SGS}}=\left(C_{\mathrm{S}} \Delta\right)^{2} \sqrt{2 S_{\mathrm{ij}} S_{\mathrm{ij}}}
$$

$\Delta$ はグリッドフィルタ幅であり，本コードでは各要素を構成する辺の長さの最小值を用いている． $S_{\mathrm{ij}}$ はひずみ速 度テンソルである. C $\mathrm{s}$ はモデル係数であり本コードではダイナミックスマゴリンスキー (Germano et al., 1991, Lilly, 1992）により計算する. 要素タイプとしては六面体要素を使用した．速度，圧力はそれぞれ節点，要素で定義さ れている. 実行時に計算格子を自動細分化する機能（吉村他，2013）を使用し，水平方向解像度 $225 \mu \mathrm{m}$, 格子 数 20 億の計算格子を用いて LES 解析を実施した。用いた計算格子は水槽の底面および側面に発達する乱流境界 層中の縦渦を解像できる. 水槽の計算モデルを図 1 に示す．境界条件および計算格子等の詳細は既報（山出他， 2019）を参照されたい.

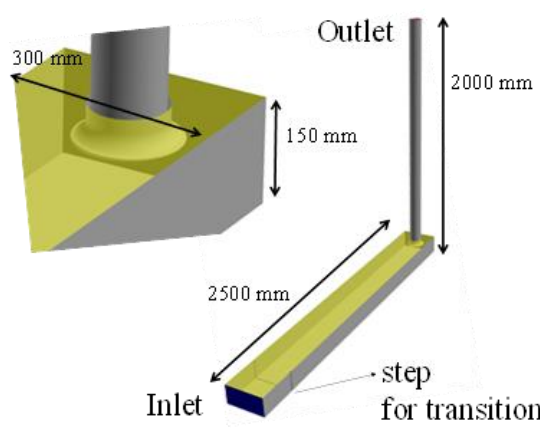

(a) Entire model and close-up view near bellmouth

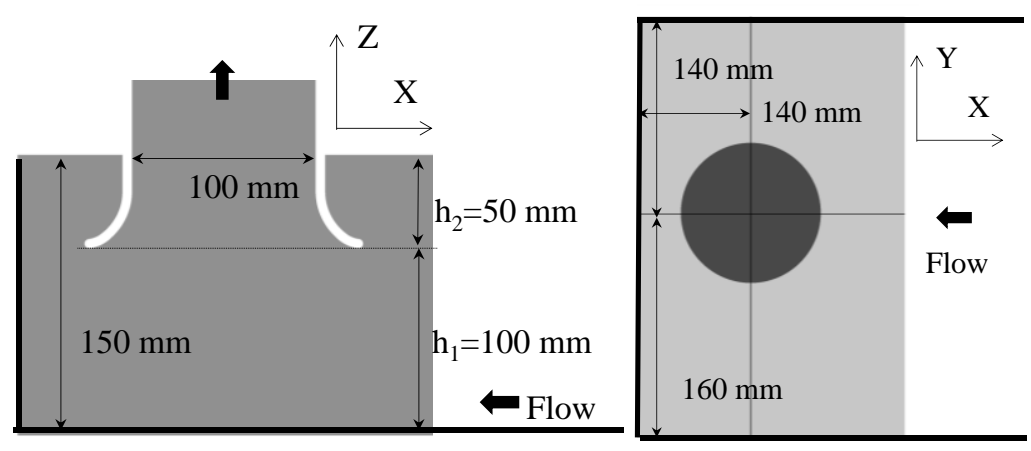

(b) X-Z section near the bellmouth

(c) X-Y section near the bellmouth

Fig. 1 Computational model of model pump sump.

\section{4. 水中渦の流れ構造}

水中渦の構造を定量的に理解するため，既報（山出他，2019）で実施したモデル水槽を対象とした LES 解析に より再現した水中渦の流速分布や静圧分布を分析する. 水中渦が現れた，典型的な瞬時の流れ場に対して，圧力 のラプラシアンの等值面を渦度の鉛直成分で色付けして表示することにより可視化された吸込渦を図 2 に示す.

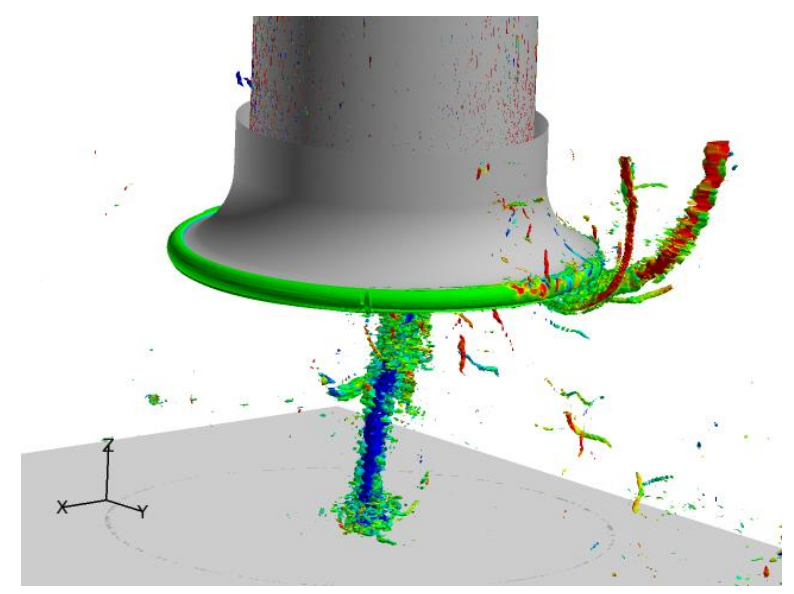

Fig. 2 Suction vortices visualized by iso-surfaces of Laplacian of static pressure colored by vertical vorticity.

吸込渦は発生したり，消滅したりする過程において，特定の場所に留まらずに振れ回る，そこで，水中渦の構造 を定量的に調べるために, 振れ回る渦と一緒に移動する座標系において流れ場に平均処理を施した. 具体的には, 
$0.324 \mathrm{sec}$ (チャネル長さおよび平均主流速度で規格化した無次元時間で約 1.2 , 計算ステップ数は 10,000）の間の 計算結果から, $1.62 \mathrm{msec}$ 間隔で出力した 200 個の瞬時の流れ場に対して, ある高さの水平断面内において静圧が 最低となる点を抽出し, この点を水中渦の中心と仮定して, 以下の式 (3)により, 軸方向速度 $C_{\mathrm{z}}$, 周方向速度 $C_{\mathrm{u}}$ および静圧 $P$ を周方向平均するとともに, 時間に対しても平均した，上記の時間において， ベルマウス入口の下 に水中渦が一つだけ存在し続けていることを確認している.

$$
\widetilde{C_{\mathrm{z}}}(r, z)=\sum_{i=1}^{\mathrm{N}_{\mathrm{t}}} \sum_{\mathrm{j}=1}^{\mathrm{N}_{\theta}} \frac{C_{\mathrm{z}}(r, z)_{\mathrm{i}, \mathrm{j}}}{N_{\mathrm{t}} N_{\theta}}
$$

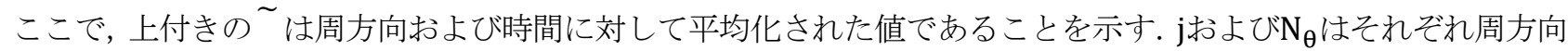
の位置に関するインデックスおよび周方向のデータ数であり, ここでは $\mathrm{N}_{\theta}=360$ とした．また， $\mathrm{i} お よ ひ ゙ \mathrm{~N}_{\mathrm{t}}$ はそ れぞれ時間に関するインデックスおよびデータ数であり, 上記のとおり $\mathrm{N}_{\mathrm{t}}$ は 200 である. 式 (3) は軸方向速度成 分 $C_{\mathrm{Z}}$ に対する平均処理を示したが，他の流速成分および静圧に対しても同じ平均処理をした. 式 (3)により平均 化された速度成分および静圧の半径方向分布を図 3 に示寸. 図中のZは水槽の底面からの高さを表す. 図 1 (b)に 示したようにベルマウス下端は $Z=100 \mathrm{~mm}$ である. 周方向速度 $C_{\mathrm{u}}$ は渦の中心近くでは $C_{\mathrm{u}} / \mathrm{r}$ が一定となる岡体回 転の渦, その外側ではr $C_{\mathrm{u}}$ が一定となる自由渦から構成されるランキン渦の速度分布を示している. この流速分布 に対応して, 渦の中心に近づくにつれて静圧が低下し, 渦の中心（r=0）で静圧は最小となるが, 静圧低下量はお よそ $4 \mathrm{kPa} \sim 5 \mathrm{kPa}$ であり，大気圧の 4\%〜 $5 \%$ 程度であった．なお，静圧は各水平断面における半径 $54 \mathrm{~mm}$ の位置 における静圧の值との差であり, 静水圧は考慮していない. 静圧の降下量は, 渦の周方向速度分布を理想的なラ ンキン渦のそれと仮定し，半径方向の平衡条件式を積分して求めた值よりも大きかったが，ほぼ半径方向の平衡 条件が成立していた。 一方, 軸方向の流速分布に関しては, 底面 $(Z=0 \mathrm{~mm})$ では $C_{\mathrm{z}}=0$ であり, ベルマウス入口 近くの $Z=90 \mathrm{~mm}$ の水平断面では中央で $C_{Z} \sim 2.0 \mathrm{~m} / \mathrm{s}$ になっており, 軸方向速度の最大值はおよそ高さ $Z$ に比例し て大きくなる. また，渦中心近傍では，局所的に $C_{\mathrm{z}}$ が大きくなる特徴が確認できる. 実験で観測される水中渦の 中心とその近傍には気相 (キャビテーション) が発生し, そこでの静圧は飽和蒸気圧 (常温の水の場合は $2.3 \mathrm{kPa}$ ) まで下がっていることが推定されるため, 静圧降下量は大気圧, 寸なわち, $100 \mathrm{kPa}$ 程度と推定される. したがっ て, 本 LES 解析は渦の中心近傍の静圧降下量を大幅に過小評価していると考えられる. 本論文では渦の中心から 周方向速度が最大となる半径までの領域を渦コアと定義することにするが, 渦コアの半径はおよそ 3 4 mm であ った. 本 LES 解析の水平方向の格子解像度 $225 \mu \mathrm{m}$ であるが，この LES 解析では，水中渦の中心近傍における 速度分布および静圧の勾配を表現できていなかったと言える. そこで, 次節以降では一つの水中渦を対象にして, 格子解像度を上げて実施した LES 解析（以下，簡易モデルによる LES 解析と称する）について議論する.

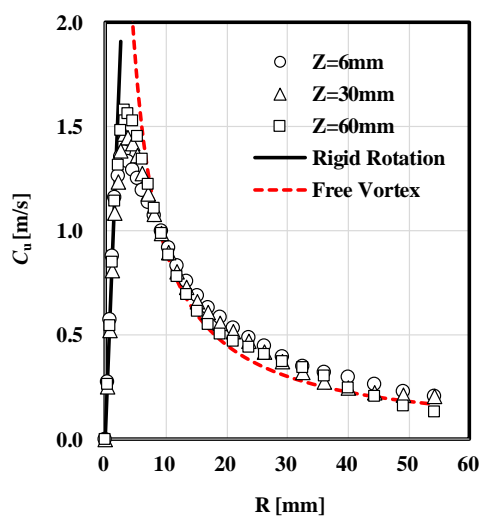

(a) $\mathrm{Cu}$

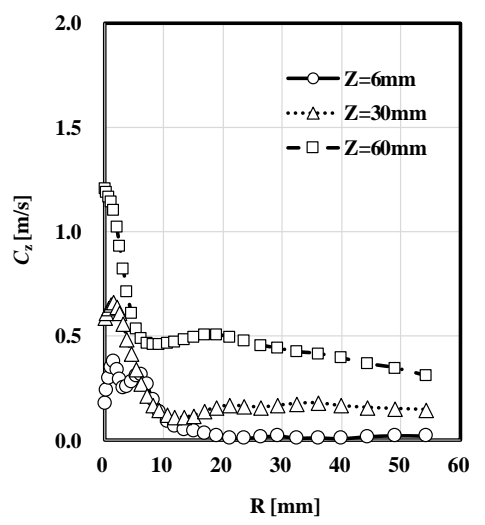

(b) $C_{\mathrm{z}}$

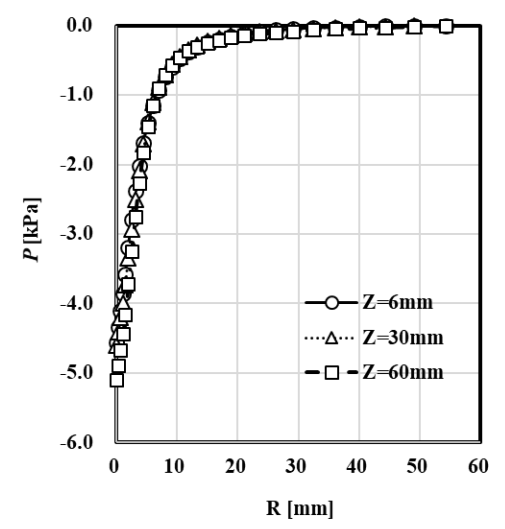

(c) Static pressure

Fig. 3 Radial distributions of velocity components and static pressure averaged with respect to time and circumferential direction around the center of a submerged vortex. 


\section{5. 簡易モデルの計算条件}

\section{(1) 計算モデル}

前節に示した水槽全体の LES 解析では水平方向の解像度不足により渦コアの予測精度に問題があることがわ かったため，水平方向の格子解像度を $225 \mu \mathrm{m}$ から $15 \mu \mathrm{m}$ にあげた計算を実施した．渦コアでは圧力の押し込 み仕事が旋回運動の運動エネルギーに変換され，さらに，運動エネルギーの一部は熱に散逸する．渦コアの半径 が小さくなると，散逸量が急激に大きくなるため，渦コアの半径には最小值が存在する．渦コアの半径を正確に 計算するためには，渦コア領域においてサブグリッド・スケールの動粘性係数が動粘性係数と比較して十分に小 さくなっている必要があるが，DSM を使用した本研究ではそのことが実現されていることは確認している．ただ し，解像度 $15 \mu \mathrm{m}$ の計算格子を吸込水槽全体に適用した場合，現状の 100 倍規模（2,000 億規模）の計算格子が 必要となり現実的ではないので,計算領域を水中渦の中心近傍の領域に限定した. 計算格子数は約 600 万である. ベルマウス下の流れの特徴である加速流れを表現するために，計算領域は式（4）で表されるような，半径 $R$ が高 さ $Z$ の平方根に反比例して小さくなる回転放物体とした.

$$
R(Z)^{2} Z=R_{r}^{2} Z_{\mathrm{r}}
$$

ここで, $Z_{\mathrm{r}}$ および, $R_{\mathrm{r}}$ はそれぞれ計算領域の底面の高さ，および，その高さにおける半径であり，本計算では $Z_{\mathrm{r}}=$ $30 \mathrm{~mm}, R_{\mathrm{r}}=30 \mathrm{~mm}$ とした. 回転放物体では断面積が高さ $Z$ に反比例するため, 連続の式から軸方向速度 $C_{Z}$ の 断面内の平均值は高さ $\mathrm{Z}$ に比例し， $C_{\mathrm{Z}}$ の断面内の平均值の軸方向勾配が一定となる加速流れが実現される. 図 4 に簡易計算の計算モデルを示す．解析領域の底面は簡易計算モデルの流入境界とし，以下に示すランキン渦の周 方向速度分布 $C_{\mathrm{u}, \text { inlet }}$, および, 軸方向速度分布 $C_{\mathrm{z}, \text { inlet }}$, 半径方向速度分布 $C_{\mathrm{r}, \text { inlet }}$ 与えた.

$$
\begin{aligned}
& C_{\mathrm{z}, \text { inlet }}=C_{\mathrm{z} 0} \\
& C_{\mathrm{u}, \text { inlet }}= \begin{cases}C_{\mathrm{u} 0} \frac{R}{R_{0}} & \left(R<R_{0}\right) \\
C_{\mathrm{u} 0} \frac{R_{0}}{R} & \left(R \geq R_{0}\right)\end{cases} \\
& C_{\mathrm{r}, \text { inlet }}=0
\end{aligned}
$$

ここで, $C_{\mathrm{z} 0}, R_{0}, C_{\mathrm{u} 0}$ はぞれぞれ，流入境界における軸方向速度，渦コアの半径，渦コア半径における周方向速度 であり，これらの值は，前節に示したモデル水槽に発生する水中渦の LES 解析における高さ $\mathrm{Z}=30 \mathrm{~mm}$ の位置の 平均速度分布から, $R_{0}=3.0 \mathrm{~mm}, C_{\mathrm{Z} 0}=0.6 \mathrm{~m} / \mathrm{s}, C_{\mathrm{u} 0}=2.94 \mathrm{~m} / \mathrm{s}$ とした. 図 3 (a) に示すとおり, ポンプ吸込水槽を 対象とした LES 解析において計算された水中渦はランキン渦に近い流速分布をしているため, これを模擬するた めの簡易形状を対象とした LES 解析における初期值（流入境界で与える流速分布）としてもランキン渦の流速分 布を与えた. ただし, 周方向速度 $C_{\mathrm{u} 0}$ に関しては, 図 1 に示した水槽の LES 解析で求まった高さ $30 \mathrm{~mm}$ の水平断 面の渦コア半径 $(3.0 \mathrm{~mm})$ における周方向速度は粘性の影響を受けているので, 簡易モデルとモデル水槽とで, 自由渦領域の周方向速度 $C_{\mathrm{u}}$ の分布，つまり，これらの計算における渦の循環が一致するように調整して与えた. また，軸方向速度 $C_{\mathrm{z} 0}$ は図 3 に示した水槽計算で求まった高さ $30 \mathrm{~mm}$ の水平断面の最大軸方向速度をモデル計算 の底面で一様に与えた. このことにより，モデル計算における軸方向の加速が水槽の LES 解析のそれよりも大き くなった可能性もあるが，この点に関しては次節にて，LES 計算の格子解像度や時間刻み幅の影響と併せて言及 する．なお，計算領域の外側境界ではノンスリップ条件を与え，また，流出境界では静圧勾配と流体力が零とい う条件を与えた。これらの境界条件はランキン渦の速度分布や，周方向速度分布と半径平衡条件から決まる静圧 分布とは整合しないが，解析領域の半径は十分に大きく取ってあり，また，流出境界は図 4 に示すように，ダミ 一領域を設けることにより十分に下流に設定しているため，これらの境界条件が計算結果に与える影響は無視で きることを予備計算により確認している。一方，計算の初期条件に関しては次のように与えた，すなわち，軸方 
向速度 $C_{\mathrm{z}}$, および半径方向速度 $C_{\mathrm{r}}$ にはそれぞれ 0 を与え, また, 周方向速度 $C_{\mathrm{u}}$ に関しては, 渦コアの半径は計 算モデルの半径に比例して小さくなり, 自由渦の領域の循環量は半径方向にも軸方向にも変化しないものと仮定 して, 上述の式 (5) に示すランキン渦の流速分布を与えた. また, 静圧の初期值は半径平衡条件（周方向速度に より生じる遠心力と静圧分布が釣り合う条件）から求まる，以下に示す圧力分布を与えた.

$$
P_{\text {initial }}=\left\{\begin{array}{c}
P_{\infty}-\rho C_{\mathrm{u} 0}^{2}+\frac{\rho}{2} C_{\mathrm{u} 0}^{2}\left(\frac{R}{R_{0}}\right)^{2} \quad\left(R<R_{0}\right) \\
P_{\infty}-\frac{\rho}{2} C_{u 0}^{2}\left(\frac{R_{0}}{R}\right)^{2} \quad\left(R \geq R_{0}\right)
\end{array}\right.
$$

ここに, $P_{\infty}$ は解析領域の外側の境界における静圧であり, 本解析では $P_{\infty}$ は零とした. 以上の条件による計算をべ ースラインケースと称することにする.

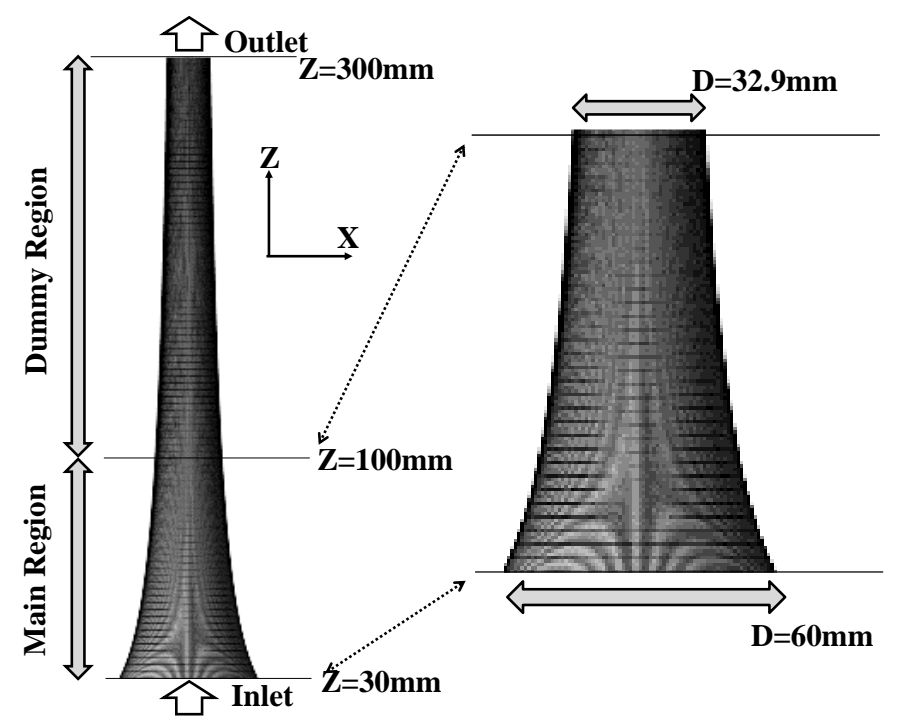

Fig. 4 Simplified computational model for a single submerged vortex.

Table 1 Summary of test cases for computing submerged vortex in pump-sump model and simplified model.

\begin{tabular}{|c|c|c|c|c|c|}
\hline $\begin{array}{l}\text { case } \\
\text { name }\end{array}$ & $\begin{array}{l}\text { computational } \\
\text { model }\end{array}$ & $\begin{array}{l}\text { grid resolution } \\
{[\mu \mathrm{m}]}\end{array}$ & $\begin{array}{l}\text { time increment } \\
{[\mathrm{sec}]}\end{array}$ & $\begin{array}{l}\text { tangential } \\
\text {-velocity ratio } \\
\qquad \alpha\end{array}$ & $\begin{array}{c}\text { axial-velocity ratio } \\
\beta\end{array}$ \\
\hline - & Pump-sump Model & 225 & $3.2 \times 10^{-5}$ & - & - \\
\hline Baseline & Simplified Model & $\underline{15}$ & $3.1 \times 10^{-6}$ & $1.0\left(C_{\mathrm{u} 0}=2.94 \mathrm{~m} / \mathrm{s}\right)$ & $1.0\left(C_{\mathrm{z} 0}=0.6 \mathrm{~m} / \mathrm{s}\right)$ \\
\hline Case A & \multirow{4}{*}{$\begin{array}{l}\text { Simplified Model } \\
\text { Simplified Model } \\
\text { Simplified Model } \\
\text { Simplified Model }\end{array}$} & $\underline{3.25 \sim 150}$ & $3.1 \times 10^{-6}$ & 1.0 & 1.0 \\
\hline Case B & & 15 & $\underline{1.2 \times 10^{-5}}$ & 1.0 & 1.0 \\
\hline Case C & & 15 & $3.1 \times 10^{-6}$ & $\underline{0.05 \sim 1.50}$ & 1.0 \\
\hline Case D & & 15 & $3.1 \times 10^{-6}$ & 1.0 & $\underline{0.15 \sim 2.2}$ \\
\hline
\end{tabular}

\section{(2) 計算ケース}

本研究では, 格子解像度や時間刻みなどの数值計算に関するパラメータ, および流入境界に与える旋回強さや 軸方向速度などの条件が渦の成長や静圧降下に与える影響を調査するため，前節に示したベースラインケースに 加え, 計算条件を変更したケーススタディを実施した。始めに, 計算格子の解像度の影響を調べるため, 計算格 子解像度を $3.25 \mu \mathrm{m}$ から $150 \mu \mathrm{m}$ の範囲で変更した計算（以下，ケース $\mathrm{A}$ と称する.）を実施した. 次に時間刻 みの影響を調査するため, ベースラインケースに対し，時間刻みを基準值の $3.1 \times 10^{-6} \mathrm{sec} よ り 4$ 倍大きくした計 
算（以下，ケース $\mathrm{B}$ と称する.）を実施した。一方，渦の条件に関しては，流入境界で与える周方向速度の最大值 $C_{\mathrm{u} 0}$ をベースラインケースの $C_{\mathrm{u} 0}$ を基準にして，0.05 $C_{\mathrm{u} 0}$ から $1.5 C_{\mathrm{u} 0}$ まで 22 通り（ベースラインケースを含む）に 変化させた計算（以下，ケース $\mathrm{C}$ と称する.）を実施した. 最後に, 流入境界で与える軸方向速度 $C_{\mathrm{z} 0}$ をベースラ インケースの $C_{\mathrm{z} 0}$ を基準にして，0.15 $C_{\mathrm{z} 0}$ から $2.2 C_{\mathrm{z} 0}$ まで 9 通り（ベースラインケースを含む）に変化させた計算

（以下，ケース D と称する.) を実施した．ケース C およびケース D はそれぞれ，水中渦の初期循環および軸方 向速度の違いがその後の渦の発達に及ぼす影響を調査するために実施したものである. 既報 (山出他, 2019) で実

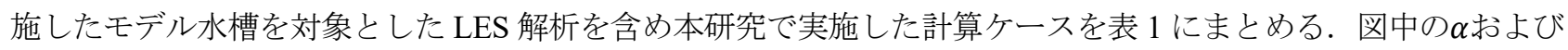
$\beta$ はそれぞれ，流入境界で与える周方向速度の最大值 $C_{\mathrm{u} 0}$ および軸方向速度 $C_{\mathrm{z} 0}$ をべースラインケースにおける值 で無次元化した值である.

\section{6. 簡易モデルの計算結果}

(1) ベースラインケース

図 5 にベースラインケースにおいて計算された高さ $60 \mathrm{~mm}$ の断面 (簡易モデルの流入境界から $30 \mathrm{~mm}$ の断面) における渦中心近傍の瞬時の速度分布を示寸. 図 5 に示寸 3 個の円の半径はそれぞれ半径 $0.6 \mathrm{~mm}, 1.5 \mathrm{~mm}, 3.0$ $\mathrm{mm}$ である. また, 図 6 に高さ $60 \mathrm{~mm}$ の断面における解析領域の中心と半径 $15 \mathrm{~mm}$ の点の静圧差の時系列を示 す. 半径 $15 \mathrm{~mm}$ の点における静圧は渦の旋回運動の影響をほとんど受けていないため, 上記の静圧差は解析領域 の中心の静圧降下量を表している. 前述のように, 本計算では高さ $30 \mathrm{~mm}$ の断面を流入境界として, 渦コアの半 径が $3.0 \mathrm{~mm}$ のランキン渦の流速分布を与えたが, 高さが $30 \mathrm{~mm}$ 上昇する間に渦コアの半径は $1 \mathrm{~mm}$ 以下に縮小 し, 渦コア部の軸方向速度は流入境界で与えた速度の約 5 倍に増速している. 簡易モデルによる計算結果は, モ デル水槽に生じる水中渦と同様に, 渦の中心は解析領域の中心にはなく, 図示はしていないが周方向速度成分と 同じ方向に振れ回っている. また, 図 6 に示寸静圧降下量の時間平均值は $106.4 \mathrm{kPa}$ であり, その変動 (Root Mean Square value, 以下 RMS 值）は $3.93 \mathrm{kPa}$ （静圧降下量の時間平均值の $3.7 \%$ ）であった. なお，実際の現象では, 圧力が飽和蒸気圧以下に下がった時点でキャビテーションにより気相が発生寸るため, それ以上圧力が下がるこ とはないが，本研究における計算では気相の発生を考慮していないため, 圧力は飽和蒸気圧以下まで下がってい る. 静圧変動量は時間平均した静圧降下量の 4\%程度である. 式 (6) に示したように, 渦の中心近傍の静圧は中 心からの距離の 2 乗に比例して変化し, 後述寸る図 7(b)に示した平均静圧分布からわかるように, 渦コア半径の 内側の領域では半径が約 $0.6 \mathrm{~mm}$ 変化する間に約 $50 \mathrm{kPa}$ 変化する. したがって, 渦中心がわずかに振れ回ってい るだけでも解析領域の中心静圧は大きく変動寸る.解析領域中心の静圧変動が比較的大きいのはこのためである.

高さ $60 \mathrm{~mm}$ の断面において, ベースラインケースの解析および水槽内部流れの解析のそれぞれにより計算され た, 周方向速度および静圧の半径方向の分布を図 7 に比較する. ここで, 簡易モデルによる解析結果は解析領域 の中心まわりに平均処理をしたものである. 図 7 では渦中心近傍の両者の分布の違いを明確にするため横軸は対 数表示している. 水槽計算で求まった周方向速度と静圧の分布はそれぞれ, 図 3(a) と同(c)に示した分布の横軸を 対数に変更して再掲したものである. 前述のように, 本研究では周方向速度が最大值をとる半径を渦コアの半径 と定義しているが，水槽の計算では底面からの高さ $30 \mathrm{~mm}$ の断面から同 $60 \mathrm{~mm}$ の断面に至る, 高さが $30 \mathrm{~mm}$ 上 昇する間に渦コア半径はほとんど縮小してなく, 周方向速度の最大值もほとんど増大していない. このため, 高 さ $60 \mathrm{~mm}$ の断面における, 渦中心の静圧の降下量は高さ $30 \mathrm{~mm}$ の断面のそれと比較するとわずかには増大して いるものの, 高々 $5 \mathrm{kPa}$ 程度に留まっている. なお, 水槽内部流れの解析では, 図 $3(\mathrm{~b})$ に示すように, 渦コア領域 に現れる軸方向速度の最大值は高さが $30 \mathrm{~mm}$ 上昇する間に, 約 $0.6 \mathrm{~m} / \mathrm{s}$ から約 $1.2 \mathrm{~m} / \mathrm{s}$ に 2 倍程度増大している が, 連続の式の関係から渦コア領域全体で軸方向速度が増大しているわけではなく, 渦の中心近傍でのみ軸方向 速度は増大していることになる。これに対して, 簡易モデルによる計算では, 高さ $60 \mathrm{~mm}$ の断面において渦コア の半径が約 $0.75 \mathrm{~mm}$ となり, 高さが $30 \mathrm{~mm}$ 上昇する間に渦コアの半径が約 $1 / 4$ に縮小している. このことに伴 い, 周方向速度 $C_{\mathrm{u}}$ の最大值が $8.0 \mathrm{~m} / \mathrm{s}$ (水槽計算の 5.0 倍), 静圧降下量が前述のとおり $106.4 \mathrm{kPa}$ (水槽計算の約 21 倍）になった．渦コア半径における周方向速度（最大の周方向速度）は既に粘性の影響を受けていると考えら れが，仮に渦コア半径まで自由渦の分布が続いていたと仮定すると，角運動量の保存則から， $0.75 \mathrm{~mm} の$ 半径に おける周方向速度は $11.8 \mathrm{~m} / \mathrm{s}$ となる. この周方向速度の最大值を用いて, 理想的なランキン渦の流速分布と半径 
方向の平衡条件を仮定し渦中心の静圧降下量を求めると $139 \mathrm{kPa}$ となり，水中渦の中心の静圧は理想的なランキ ン渦ほどは下がらないものの，第一近似的にはランキン渦の静圧降下量で見積もれることになる.

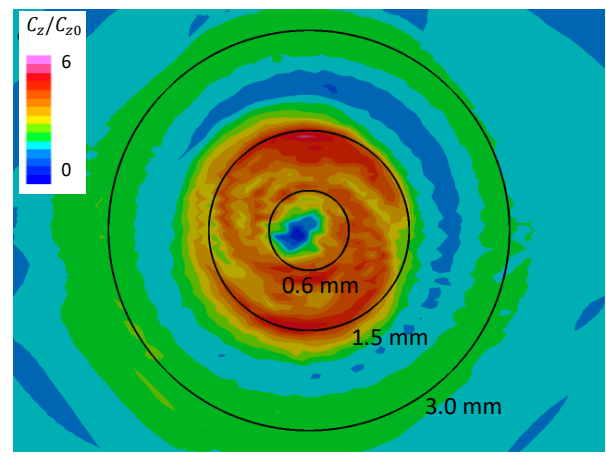

(a) $C_{\mathrm{z}}$

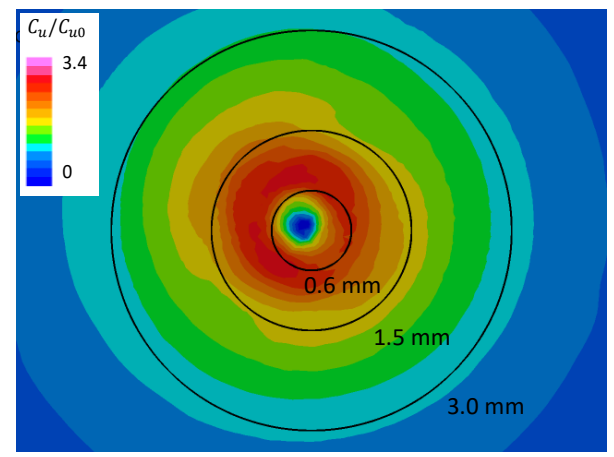

(b) $C_{\mathrm{u}}$

Fig. 5 Instantaneous axial (left) and tangential (right) velocities on the cross section at a height $\mathrm{Z}=60 \mathrm{~mm}$ in the baseline case.

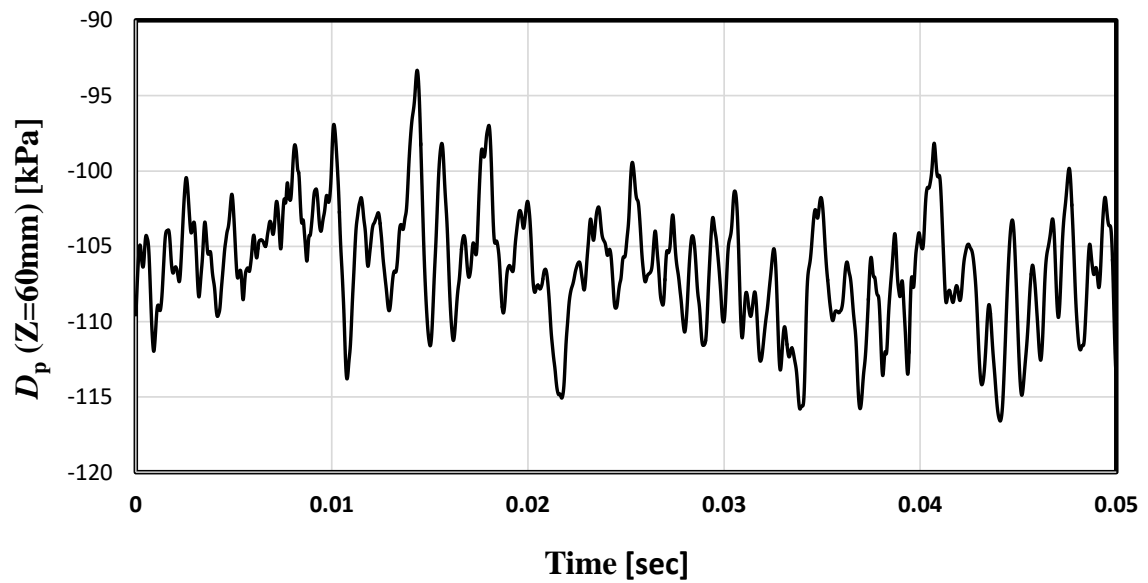

Fig. 6 Time series of static pressure at center of computational domain at height of $Z=60 \mathrm{~mm}$ in baseline case.

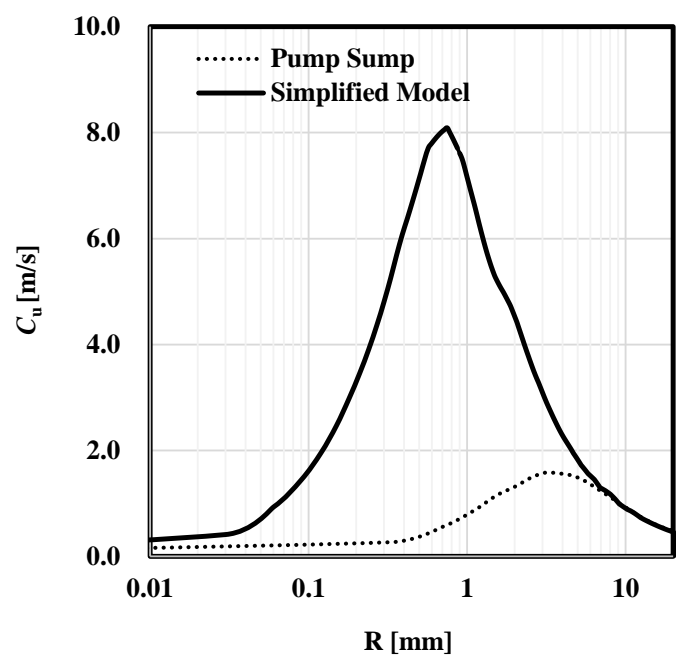

(a) $C_{\mathrm{u}}$

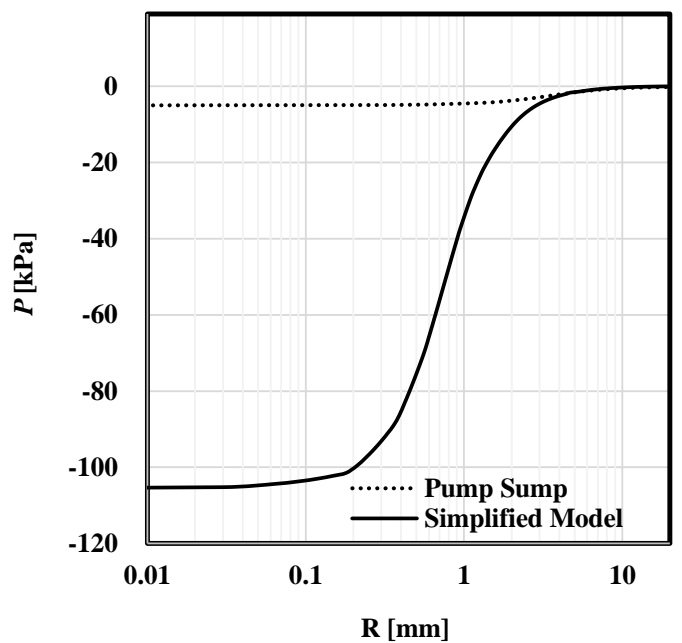

(b) Pressure

Fig. 7 Comparisons of time and circumferentially averaged radial distribution of tangential velocity and static pressure on the cross section at $\mathrm{Z}=60 \mathrm{~mm}$ in pump-sump (dashed lines) and simplified baseline (solid lines) models. 
最後に, 水槽内部流れの LES 解析において渦コアの流速分布や静圧分布が正確に再現できなかった原因につい て考察する.まず，原因の一つとして LES 計算の渦動粘性係数による散逸効果のために，渦の引き延ばしが精度 良く計算できなかったことが考えられるが, 図 3 (a)および同(c)に示した流速分布と計算格子幅から, Smagorinsky 定数の值を 0.1 と仮定して得られる渦動粘性係数のオーダは $1 \times 10^{-6} \mathrm{~m}^{2} / \mathrm{s}$ であり, 実際に計算された渦動粘性係数 の值も高々，常温常圧の水の動粘性係数と同じオーダであった．また，本研究の LES 解析では計算の安定化のた めに数值粘性も導入していない. このために, LES 計算の渦動粘性係数や数值解析のための数值粘性による散逸 効果のために渦コアの縮小（渦のストレッチ）が正確に計算されなかった可能性は考えられない. したがって, 単純に $0.225 \mathrm{~mm}$ の幅の計算格子では格子解像度が不足しており, $0.75 \mathrm{~mm}$ まで縮小寸るはずであった渦コアが再 現できなかった可能性が高い. 特に, 図3(b)からわかるように, 渦コアの境界領域において軸方向速度が急減に 変化しており，水槽計算に用いた計算格子ではこの変化を正確に捉えることができなかった可能性がある. 格子 解像度，ならびに計算の時間刻み幅が静圧降下量に与える影響については次節にて調査結果を説明する.

\section{（2）格子解像度や時間刻みと静圧降下量の関係}

格子解像度と時間刻みが計算される静圧降下量に与える影響を調査寸るため, 前述のように, ベースラインケ 一スに対して格子解像度および時間刻みを変更した計算を実施した. 格子解像度を変更するケース A では時間刻 みの影響を排除するため, すべて同じ時間刻み $\left(3.1 \times 10^{-6} \mathrm{sec}\right)$ を使用した。 また，時間刻みを変更するケース $\mathrm{B}$ では, ベースラインケースと同じ格子解像度 $15 \mu \mathrm{m}$ の計算格子を用いた。

図 8 に Case A における, 高さ $60 \mathrm{~mm}$ の断面内の計算領域中心の静圧の時刻歷を示す.これらの結果より, 格 子解像度がベースラインケースよりも粗いケース（図 8(a)）では, 静圧降下量を過小評価すること, 細かいケー ス (同図 (b)) 同士ではその差は比較的小さいことがわかる. 格子解像度が最も粗い $150 \mu \mathrm{m}$ の場合の静圧降下量

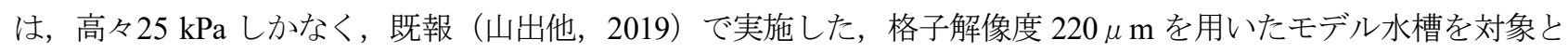
した LES 解析により計算された静圧降下量が $4 \mathrm{kPa} \sim 5 \mathrm{kPa}$ であったことと整合する. ベースラインケースの静圧 降下量が $106.4 \mathrm{kPa}$ であるのに対し，格子解像度を上げた場合の静圧降下量は，解像度 $7.5 \mu \mathrm{m}$ で $99.9 \mathrm{kPa}, 3.75 \mu$ $\mathrm{m}$ で $96.9 \mathrm{kPa}$ と格子解像度を上げると逆に節圧降下量がベースラインケースと比較して 6 10kPa 小さくなってい る. これは後述する渦の触れ回り効果とも関係しており, 渦の触れ回りが静圧降下に与える影響とともに次節に て説明する.

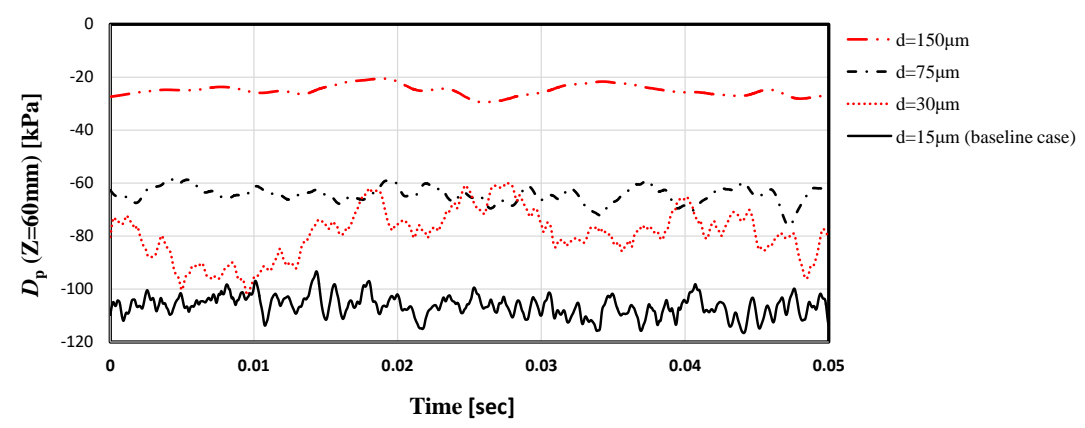

(a) Baseline case and cases with coarser computational grids

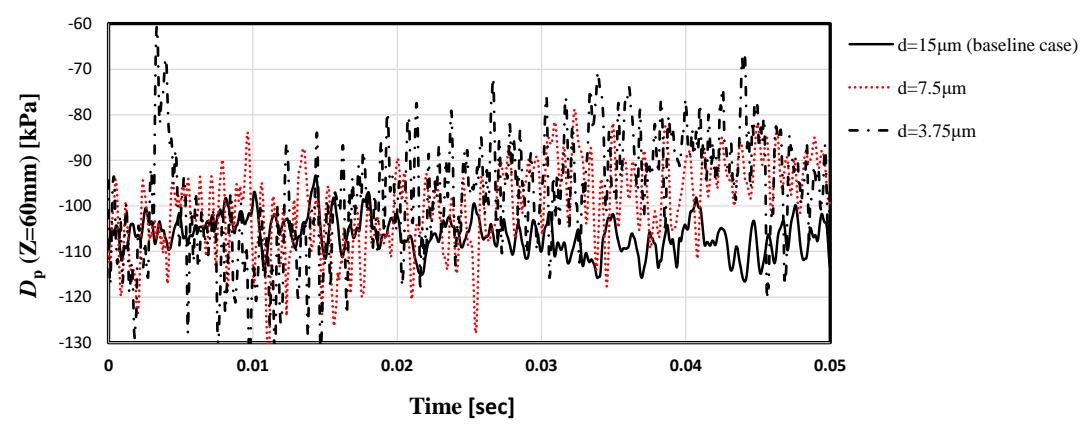

(b) Baseline case and cases with finer computational grid

Fig. 8 Time series of static pressure at center of computational domain at $Z=60 \mathrm{~mm}$ in baseline case and Case A. 
ベースラインケースおよび時間刻みを 4 倍大きくしたケース（Case B）における高さ $60 \mathrm{~mm}$ の断面内の解析領 域中心の静圧の時刻暦を図 9 に示寸.また, 両ケースの高さ $60 \mathrm{~mm}$ の断面における周方向速度の瞬時場を図 10 に示す．図 10 (a)は図 5 (b)の再掲である。ベースラインケースと比較して時間刻みを 4 倍にした Case B では静圧 降下量の時間平均值が $65.4 \mathrm{kPa}$ となっており, ベースラインケースの静圧降下量の時間平均值（106.4kPa）より も大幅に小さくなっている. 解析領域の中心に現れる, 周方向速度が小さくなる領域はケース B において極端に 拡大しており，このことに伴って，周方向速度の最大值が現れる半径が大きくなり，したがって，解析領域中心 における静圧降下量が図 9 に示したように小さくなる. 高さ $60 \mathrm{~mm}$ の断面における解析領域の中心の軸方向速度 の時刻暦およびその変動の周波数スペクトルを図 11 に示す. ベースラインケースの周波数スペクトルには $1 \mathrm{kHz}$ あたりにピークが生じているのに対し，Case B の周波数スペクトルでは，そのピークが $700 \mathrm{~Hz}$ にシフトしてお り, その変動のパワーが大きくなっている. 図 11 に示した, 軸方向速度の時間波形は約 $1.0 \mathrm{~m} / \mathrm{s}$ を平均值として, おおよそ $-1.0 \mathrm{~m} / \mathrm{s}$ から $3.0 \mathrm{~m} / \mathrm{s}$ の範囲で変動している. 後述する図 $15(\mathrm{~b}-4)$ に示すように, 軸方向速度の時間平均分 布には逆流の発生は認められず，渦が振れ回っているだけでは軸方向速度に負の值がでることは説明できない． つまり，渦コアが振れ回っていることに加えて，流れ方向（渦の軸方向）に伸び縮みしていることを意味してい る. 前述のように，時間刻みが小さなベースラインケースではこの渦コアの伸び縮み運動を正確に捉えることが できたが，時間刻みを大きくしたケース B ではこの渦コアの伸び縮み現象を正確に捉えることができなかったも のと推定される，ベースラインケースに現れた，軸方向速度の変動のピーク周波数である $1 \mathrm{kHz}$ は, 渦コア半径 における周長 (=約 $5 \mathrm{~mm})$ と同位置における周方向速度成分 (=約 $8 \mathrm{~m} / \mathrm{s})$ を使って無次元化すると, 0.6 程度に相 当する. 渦は渦コア半径における旋回速度の 6 割程度の速度で振れ回っており, 渦コアの伸び縮み現象は渦コア の振れ回り運動に同期して発生しているものと推定されるが，詳細な調査は今後の課題としたい.

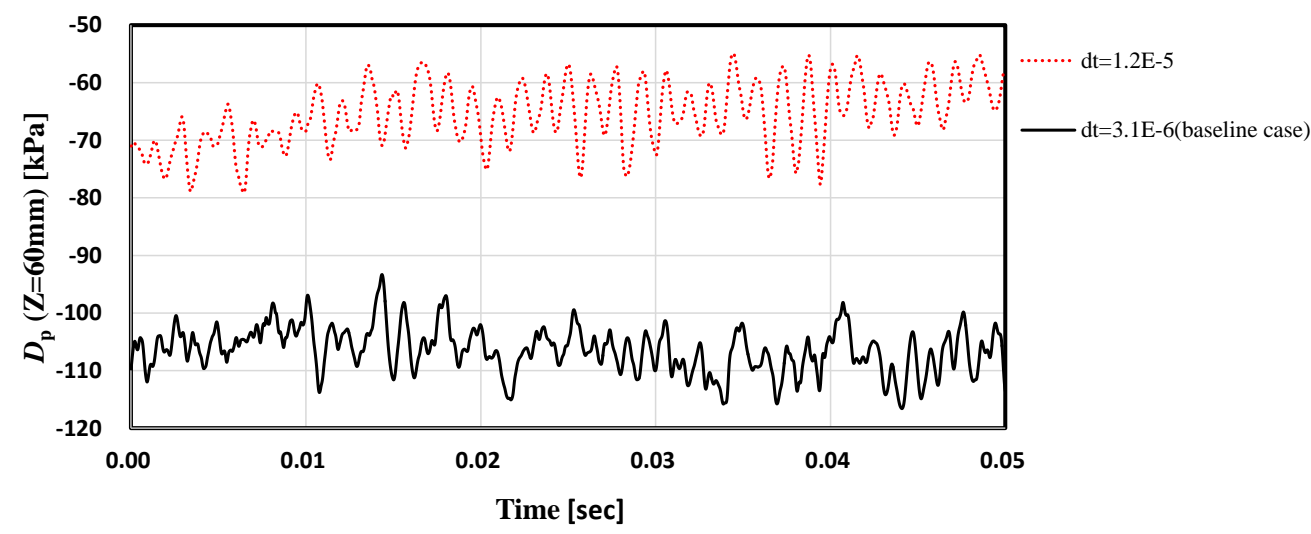

Fig. 9 Time series of static pressure at center of computational domain at $\mathrm{Z}=60 \mathrm{~mm}$ in baseline case and Case B.

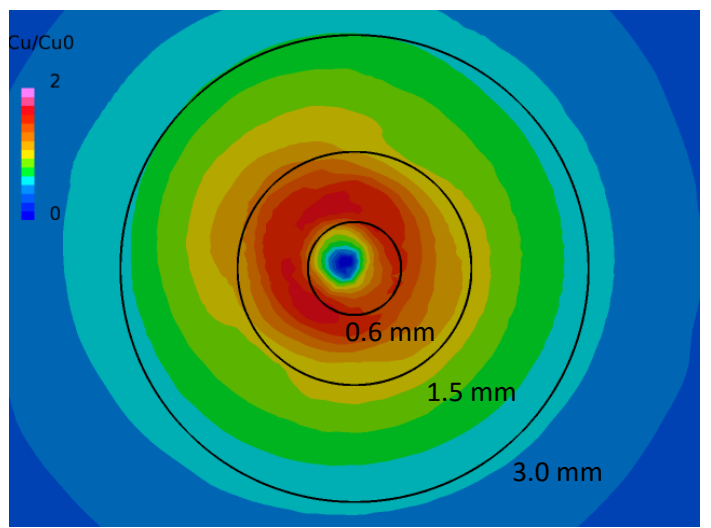

baseline case

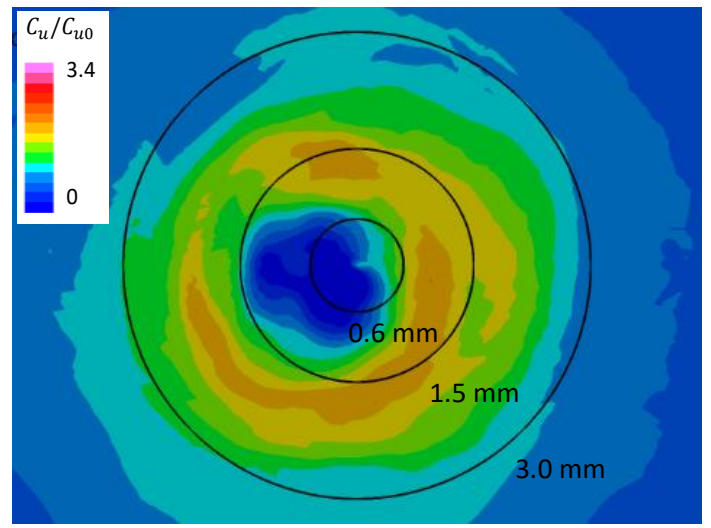

Case B

Fig. 10 Instantaneous tangential velocity $C_{\mathrm{u}}$ on the cross section at height $\mathrm{Z}=60 \mathrm{~mm}$ in the baseline case and Case $\mathrm{B}$. 


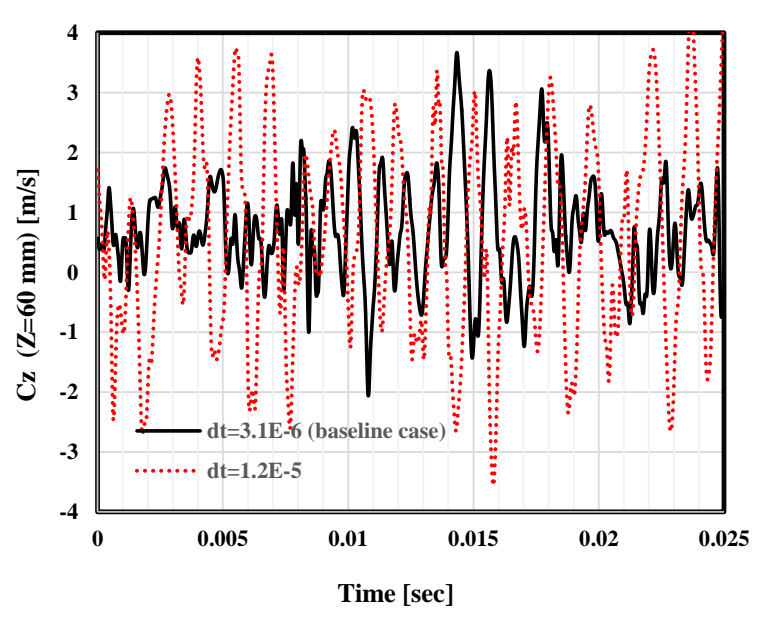

(a) Time series

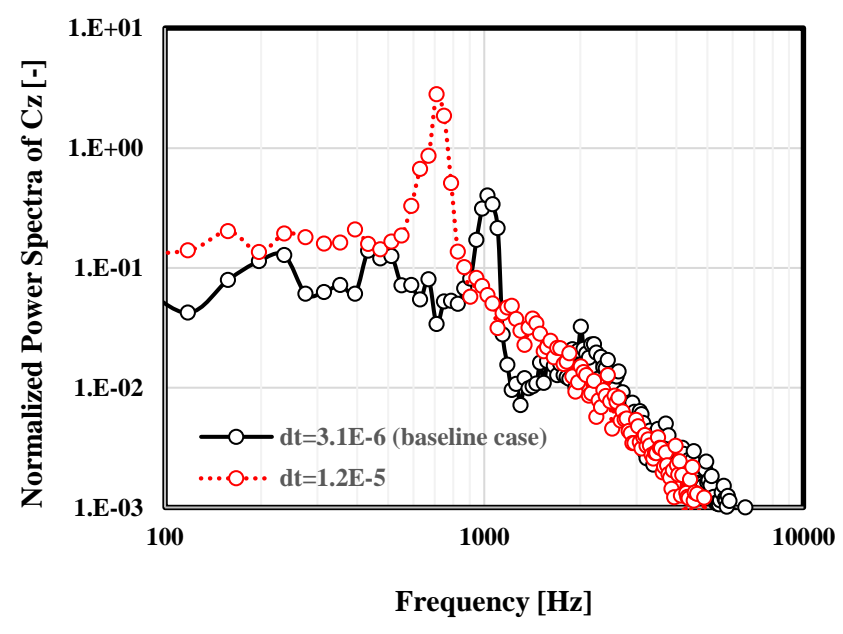

(b) Power spectrum

Fig. 11 Fluctuations (left) and its power spectra (right) of axial velocity at the center on the cross section at height $\mathrm{Z}=60 \mathrm{~mm}$ in the baseline cases and case B.

\section{(3) 初期旋回強さと水中渦の成長との関係}

既報（山出他，2019）で示したとおり，吸込水槽中の水中渦の発生過程においては，水槽の底面に境界層中の 渦度が集中する．前節では渦度が集中した結果として形成された水中渦について，計算格子の解像度や計算の時 間刻み幅と渦コアの予測精度との関係を調査するとともに，渦コアが振れ回り運動に加えて伸び縮み運動をして いることを示した．本節では，水槽の底面に集中した渦度の強度と水中渦の発生・成長との関係を調査すること を目的とし, 以下の式 (7) で定義される周方向速度の比 $\alpha$ の值を 0.05 から 1.5 まで変化させた計算を実施した.

$$
\alpha \equiv C_{u 0} / C_{\text {u0_base }}
$$

ここで， $C_{\mathrm{u} 0 \text { base }}$ はベースラインケースで流入境界に与えた最大周方向速度 $(2.94 \mathrm{~m} / \mathrm{s})$ であり，また， $C_{\mathrm{u} 0}$ は各ケ 一スで流入境界に与えた最大周方向速度である。この調査では，軸方向速度に関しては全てのケースで，ベース ラインケースで与えたものと同じ值（0.6 m/s）を与えたので，旋回流れのスワール数と流れのレイノルズ数を同 時に変化させたことになる. 流入境界において渦コア領域 (半径 $3.0 \mathrm{~mm}$ の内側の領域) を単位時間当たりに通過 する角運動量を, 同領域を単位時間当たりに通過する軸方向の運動量と渦コア半径との積で割った值でスワール 数 $\mathrm{S}$ を定義し，また，流入境界の渦コア半径と最大周方向速度（渦コア半径における周方向速度）でレイノルズ 数を定義すると, スワール数は 0.06 から 2.45 , レイノルズ数は 440 から 13,230まで変化させたことになる. 上述 したスワール数 $\mathrm{S}$ およびレイノルズ数 Re の定義, および， $\alpha, \beta$ との関係を以下に示す.

$$
\begin{aligned}
& \mathrm{S} \equiv \frac{\int_{r=0}^{r=R_{0}} r C_{u} C_{z 0} d S}{R_{0} \int_{r=0}^{r=R_{0}} C_{z 0} C_{z 0} d S}=\frac{C_{\mathrm{u}_{\mathrm{base}}}}{C_{\mathrm{z} 0_{\mathrm{base}}}} \times \frac{\alpha}{3 \beta} \\
& \mathrm{Re} \equiv C_{u 0} R_{0} / v
\end{aligned}
$$

図 12 に周方向速度比 $\alpha$ と静圧降下量の関係を示す. 静圧降下量はこれまでと同様に高さ $60 \mathrm{~mm} の$ 断面内の中 心 $(R=0)$ と渦コアの外側の点 $(R=15 \mathrm{~mm})$ の平均静圧の差により算出した. 図 $12(\mathrm{a})$ に静圧降下量の絶対值を示 すとともに, 各ケースの $C_{\mathrm{u} 0}$ から計算される動圧 $\left(\rho C_{u 0}^{2} / 2\right)$ で無次元化した静圧降下量を図 $12(\mathrm{~b})$ に示す. $\alpha$ に関 しては 22 とおりの計算を実施しているが，まず Case C における代表的な 4 ケース（ $\alpha=0.2,0.35,0.5,1.0 ）$ の流れ 
場を比較する. 高さ $60 \mathrm{~mm}$ 断面における瞬時の周方向速度を流入境界で与えた周方向速度の最大值 $C_{\mathrm{u} 0}$ で無次元 化した周方向速度 $\left(C_{\mathrm{u}} / C_{\mathrm{u} 0}\right)$ の分布を図 13 に示寸. 図 $13(\mathrm{~d})$ は図 $5(\mathrm{~b})$ の再掲である. 図 5 と同様に，図中に示す 3 個の円の半径はそれぞれ $0.6 \mathrm{~mm}, 1.5 \mathrm{~mm}, 3.0 \mathrm{~mm}$ である. $\alpha=0.2$ の場合, 周方向速度は解析領域の中心に対し て同心円状の分布をしているのに対して，他のケースでは水中渦の中心が計算領域の中心になく，周方向速度は 同心円状の分布とは異なった分布となっている.これより， $\alpha=0.2$ 以外のケースでは渦が水槽に発生する渦と同 様に振れ回っていることがわかる. 特に, $\alpha=0.5,1.0$ の 2 ケースでは, 周方向速度が流入境界で与えた $C_{\mathrm{u} 0}$ 以 上となっている領域がある。これは流入境界で与えた角運動量が渦の伸張により中心近くに輸送されていること

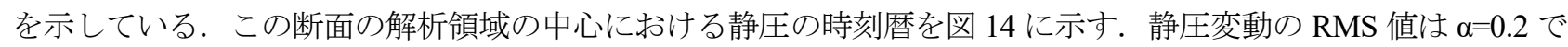
はほぼ零， $\alpha=0.35$ で $0.07 \mathrm{kPa}$ と小さいが， $\alpha=0.5$ では $2.48 \mathrm{kPa}, \alpha=1.0$ は $3.93 \mathrm{kPa}$ と急増しており, 流入境界 で与えた周方向速度が大きくなると渦の非定常性が顕著になっている.

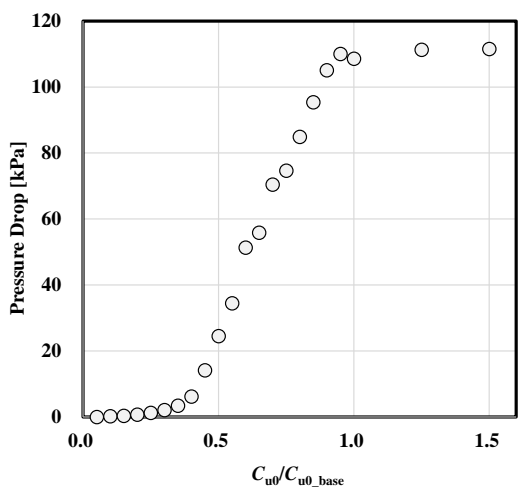

(a) Pressure drop [-]

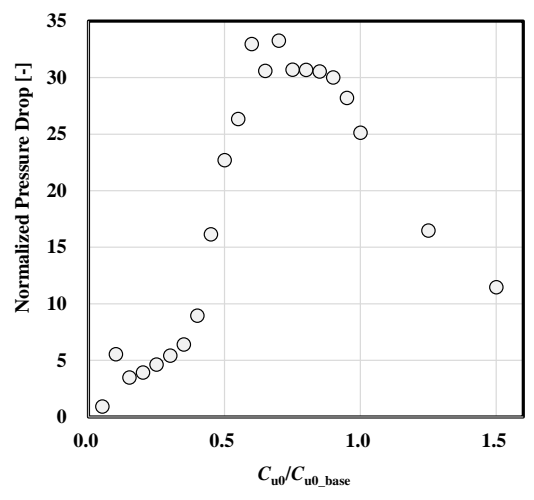

(b) Normalized pressure drop $[\mathrm{kPa}]$

Fig. 12 Effects of circulation given at inlet boundary on pressure drops at the center on the cross section at $Z=60 \mathrm{~mm}$.

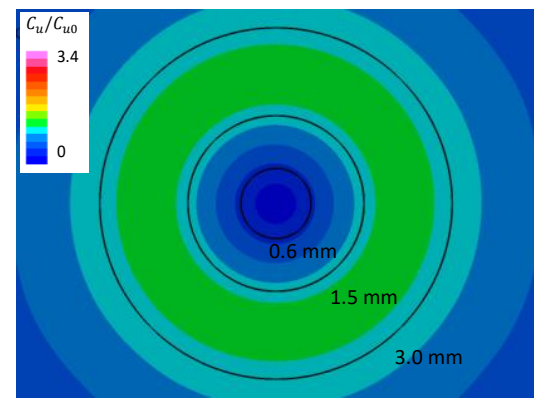

(a) $\alpha=0.2$

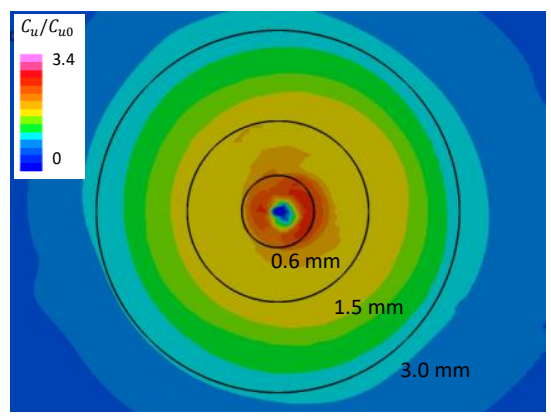

(c) $\alpha=0.5$

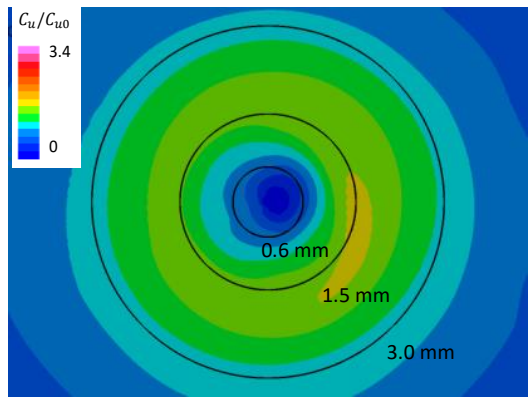

(b) $\alpha=0.35$

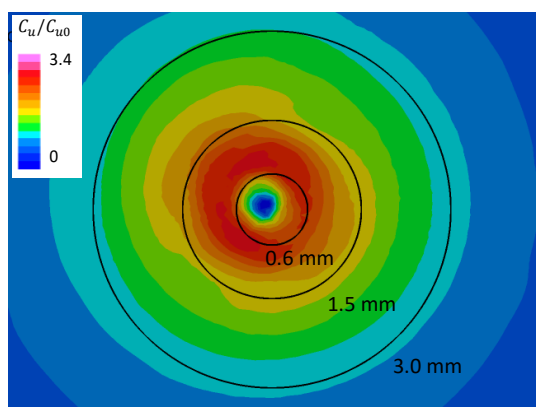

(d) $\alpha=1.0$ (baseline case)

Fig. 13 Instantaneous tangential velocity $C_{\mathrm{u}}$ normalized by $C_{\mathrm{u} 0}$ on the cross section at height $\mathrm{Z}=60 \mathrm{~mm}$ in the cases with $\alpha=0.2$, $0.35,0.5$ and 1.0 in Case C. 


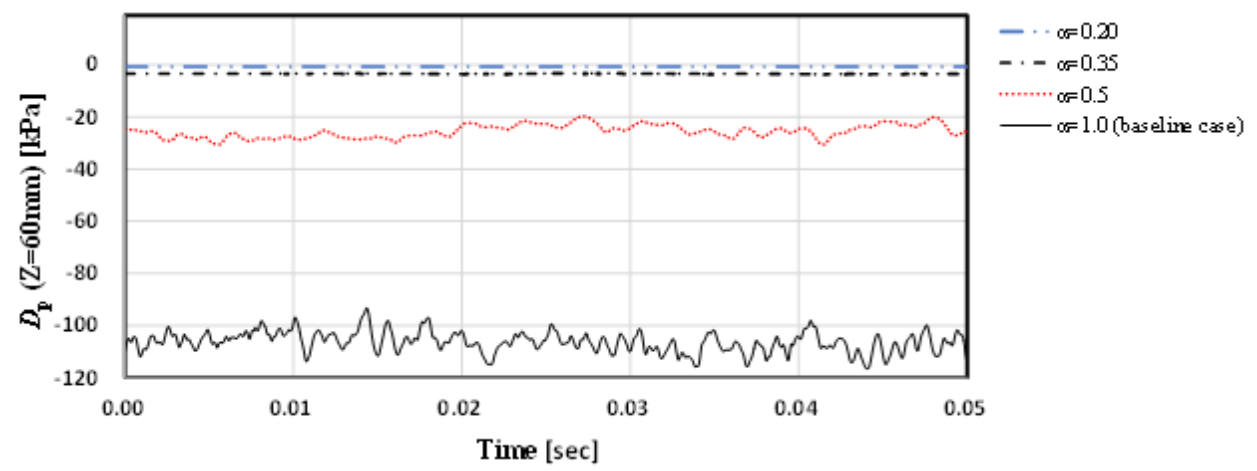

Fig. 14 Fluctuations in static pressure at the center on the cross section at height $Z=60 \mathrm{~mm}$ in the cases with $\alpha$ of $0.20,0.35,0.5$ and 1.0 .

ケース Cの 22 ケースのうち特徵的な 12 ケースについて，高さ $60 \mathrm{~mm}$ の断面における周方向速度および軸方 向速度の半径方向の分布（時間平均值）を図 15 に比較する。ここでは，後述する渦の成長に対応した 4 つに分類 している. 周方向速度および軸方向速度は流入境界で与えた各ケースの最大周方向速度 $C_{\mathrm{u} 0}$ および軸方向速度 $C_{\mathrm{z} 0}$ で無次元化している．また，周方向速度に関しては，循環が半径方向にも高さ方向にも変化しないものと仮定し た場合の自由渦の流速分布，および，以下の式（10），および（11）で表される Burgers 渦の流速分布（Burgers， 1948）を併記している. Burgers 渦は軸方向速度の軸方向の勾配が一定に保たれるものと仮定した場合の漸近解で ある.

$$
\begin{aligned}
& C_{\mathrm{u}}=\frac{C_{\mathrm{u} 0} R_{0}}{R}\left\{1-\exp \left(-\frac{R^{2}}{R_{1}^{2}}\right)\right\} \\
& R_{1}^{2}=\frac{4 v}{\left(\frac{\partial C_{z}}{\partial z}\right)}
\end{aligned}
$$

ここで， $R_{0}$ および $C_{\mathrm{u} 0}$ は自由渦の領域における半径およびそこでの周方向速度であり，ここではべースラインケ 一スの值とした。 $R_{1}$ は式（11）に示すとおり，動粘性係数 $v\left(=1.0 \times 10^{-6} \mathrm{~m}^{2} / \mathrm{s}\right)$ および軸方向速度の勾配（一定） から決まる渦コア半径である，軸方向速度の勾配は，軸方向速度が断面内に一様であると仮定し，断面積変化の 式（4）から計算したが，渦コア半径は $0.45 \mathrm{~mm}$ となる. 周方向速度の分布が高さ Z に依存しないことからわか るとおり，この解は渦が伸張しきった場合の解である．本簡易計算モデルにおいても，渦が伸張しきる十分な軸 方向長さがあり，かつ，渦が定常状態に保たれれば Burges 渦が形成された可能性はあるが，後述するように実際 に計算された渦は周方向速度比 $\alpha$ が 0.4 を超えると乱流に遷移するため Burgers 渦とは異なる流速分布となった.

高さ $60 \mathrm{~mm}$ の断面における静圧差の半径方向分布（時間平均值）を図 16 に示す. 静圧の基準值は半径 $10 \mathrm{~mm}$ における值とした，左側の図は絶対值であり，右側の図は $C_{\mathrm{u} 0}$ から計算される動圧で無次化した值である，全て のケースにおいて圧力勾配と遠心力がほぼバランスしており, 静圧と周方向速度は以下の関係式を満たしていた.

$$
\frac{\partial P}{\partial r} \cong \rho \frac{C_{u}^{2}}{r}
$$

式（12）を積分することにより，半径 Rにおける静圧差は以下の式で与えられる.

$$
P(R) \cong \int_{r=R}^{r=\infty} \rho \frac{C_{u}^{2}}{r} d r
$$


式（13）は周方向速度が大きいほど渦の中心の静圧降下が大きくなることを示している．最大周方向速度 $C_{\mathrm{u} 0}$ を 徐々に大きくする本ケーススタディでは， $C_{\mathrm{u} 0}$ が大きくなると周方向速度自体が大きくなる効果と渦の伸長によ り渦の中心近傍の周方向速度が大きくなるという二つの効果により渦の中心の静圧が降下する．図 16 (a) には $C_{\mathrm{u} 0}$ が大きくなる効果と渦の伸長効果の両方の効果が含まれ，図 16 (b) には渦の伸長効果のみが含まれる.

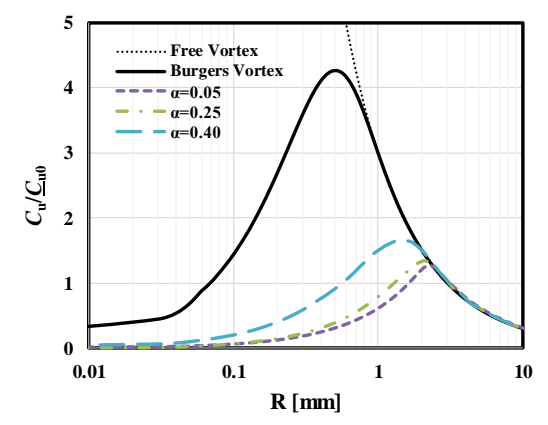

(a-1) $C_{\mathrm{u}}$ with $\alpha$ of $0.05,0.25$ and 0.40

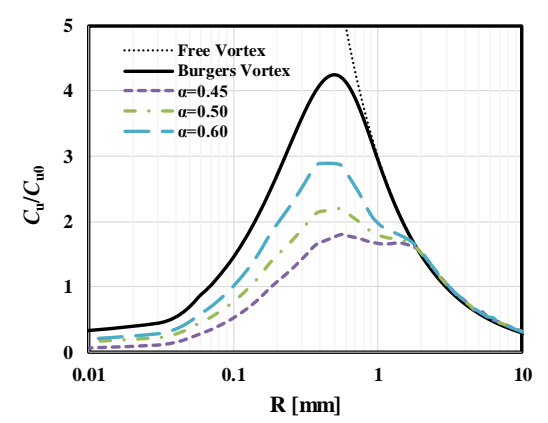

(a-2) $C_{\mathrm{u}}$ with $\alpha$ of $0.45,0.50$ and 0.60

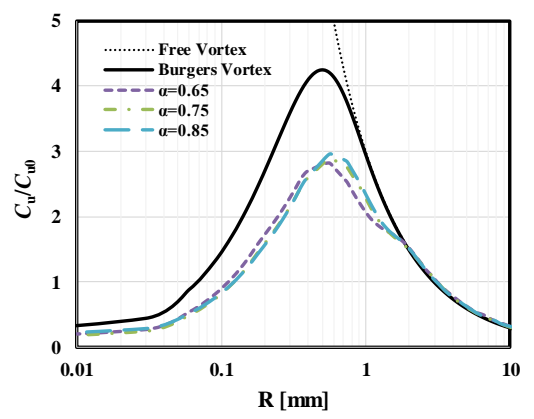

(a-3) $C_{\mathrm{u}}$ with $\alpha$ of $0.65,0.75$ and 0.85

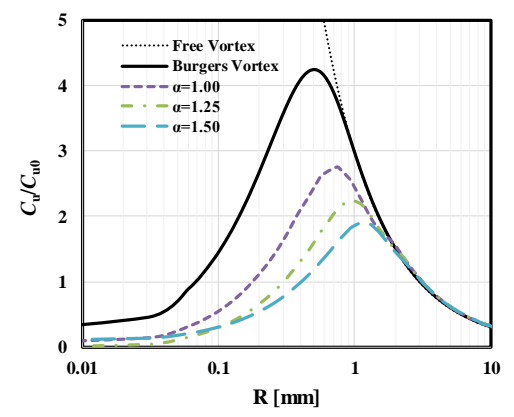

(a-4) $C_{\mathrm{u}}$ with $\alpha$ of $1.00,1.25$ and 1.50

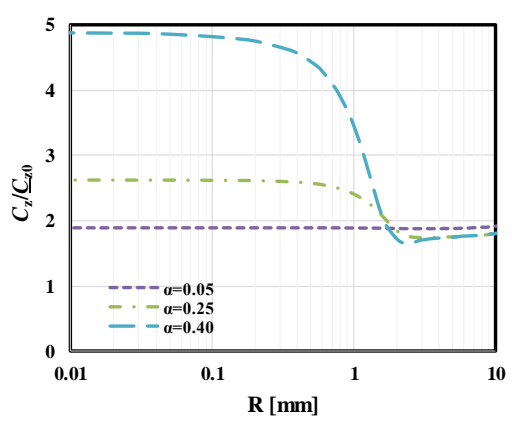

(b-1) $C_{\mathrm{z}}$ with $\alpha$ of $0.05,0.25$ and 0.40

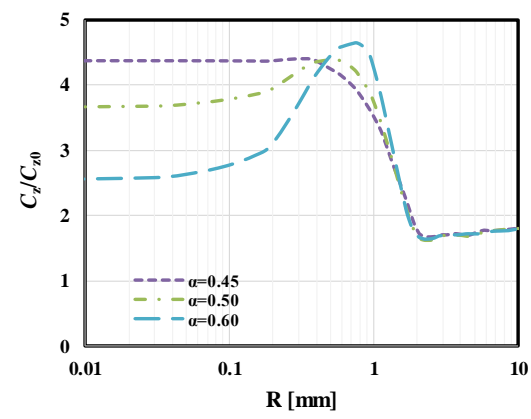

(b-2) $C_{\mathrm{z}}$ with $\alpha$ of $0.45,0.50$ and 0.60

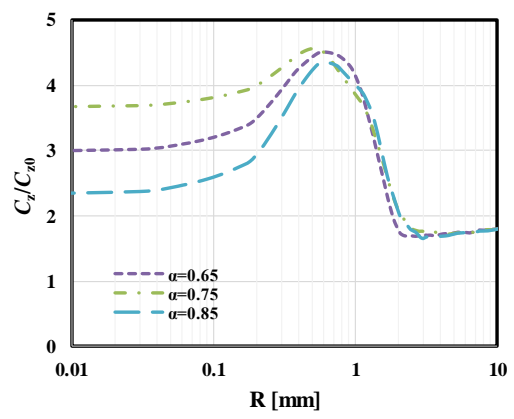

(b-3) $C_{\mathrm{z}}$ with $\alpha$ of $0.65,0.75$ and 0.85

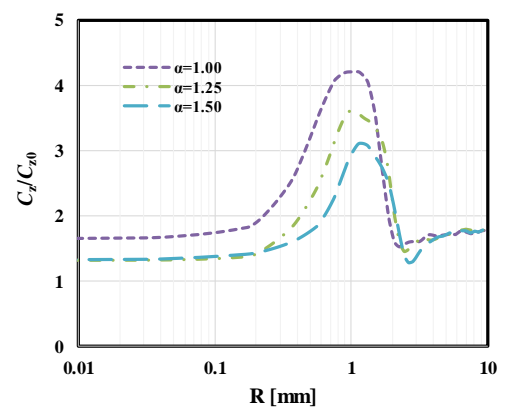

(b-4) $C_{\mathrm{z}}$ with $\alpha$ of $1.0,1.25$ and 1.50

Fig. 15 Comparisons of radial distributions of tangential (lest) and axial (right) velocities on horizontal plane at a height of $60 \mathrm{~mm}$ in Case C. 


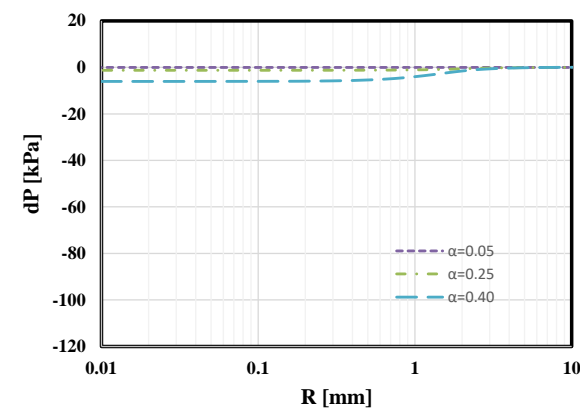

(a-1) pressure drop with $\alpha$ of $0.05,0.25$ and 0.40

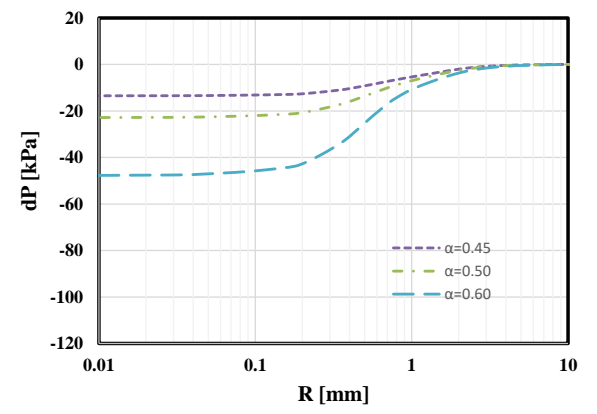

(a-2) pressure drop with $\alpha$ of $0.45,0.50$ and 0.60

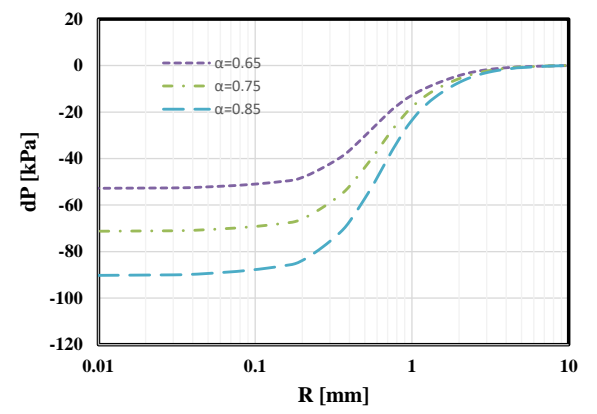

(a-3) pressure drop with $\alpha$ of $0.65,0.75$ and 0.85

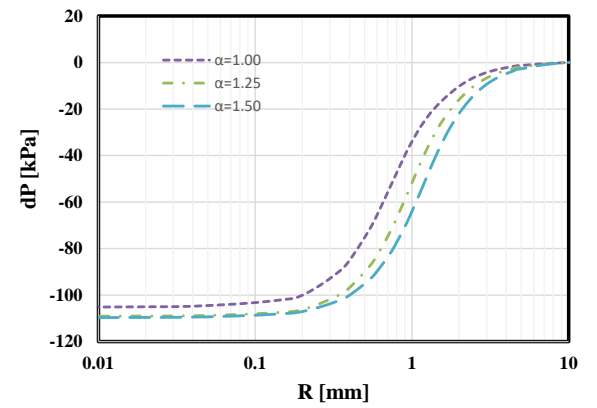

(a-4) pressure drop with $\alpha$ of $1.00,1.25$ and 1.50

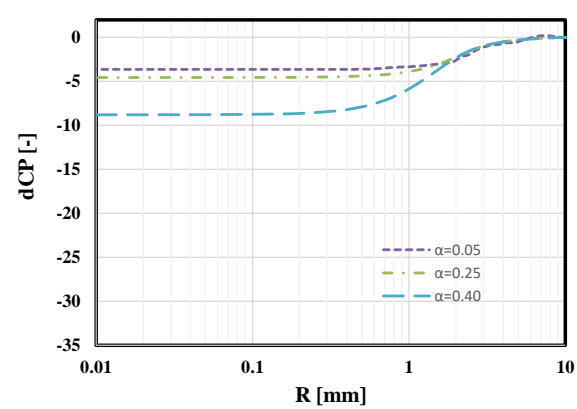

(b-1) normalized dP with $\alpha$ of $0.05,0.25$ and 0.40

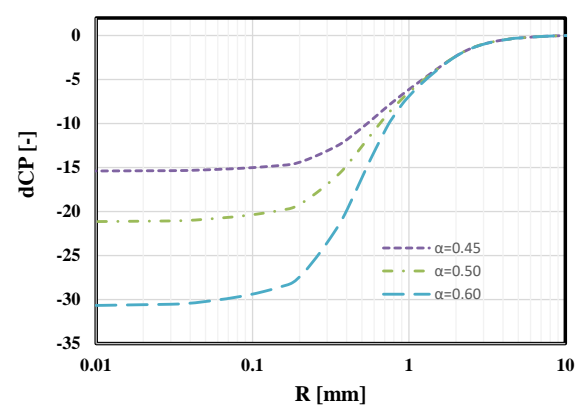

(b-2) normalized $\mathrm{dP}$ with $\alpha$ of $0.45,0.50$ and 0.60

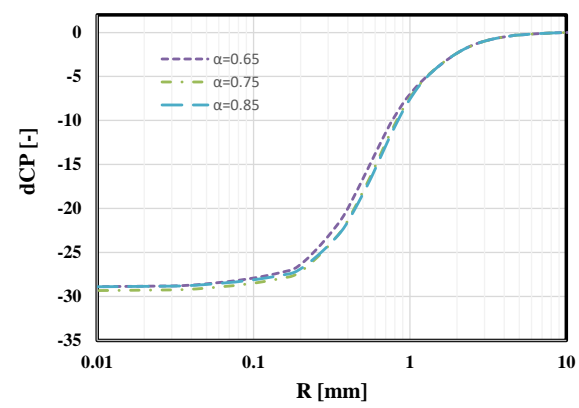

(b-3) normalized dP with $\alpha$ of $0.65,0.75$ and 0.85

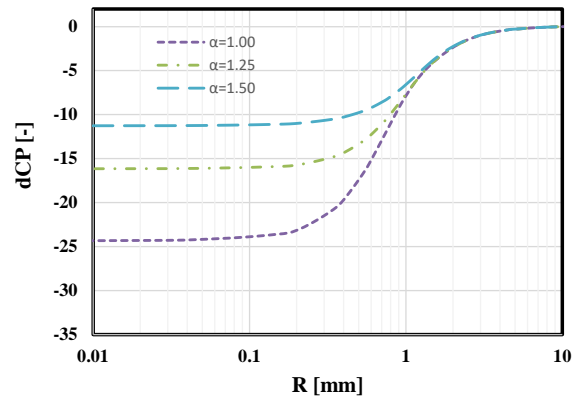

(b-4) normalized dP with $\alpha$ of $1.0,1.25$ and 1.50

Fig. 16 Comparisons of radial distributions in pressure drop on horizontal plane at a height of $60 \mathrm{~mm}$ in Case C.

流入境界で与えた周方向速度の最大值 $C_{\mathrm{u} 0}$ と高さ $60 \mathrm{~mm}$ の断面における渦コアの半径の関係を図 17 に示す. 図 15, 図 16, および図 17 から, 水中渦の成長に関する循環量の条件は次の 4 つに分類できる. 以下，各条件と その下に現れる流れ場の特徵を説明する. 


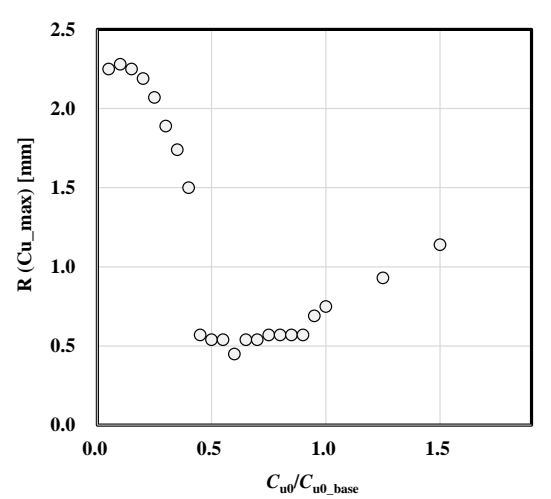

Fig. 17 Radius of vortex core computed on horizontal plane at a height of $60 \mathrm{~mm}$ in Case $\mathrm{C}$.

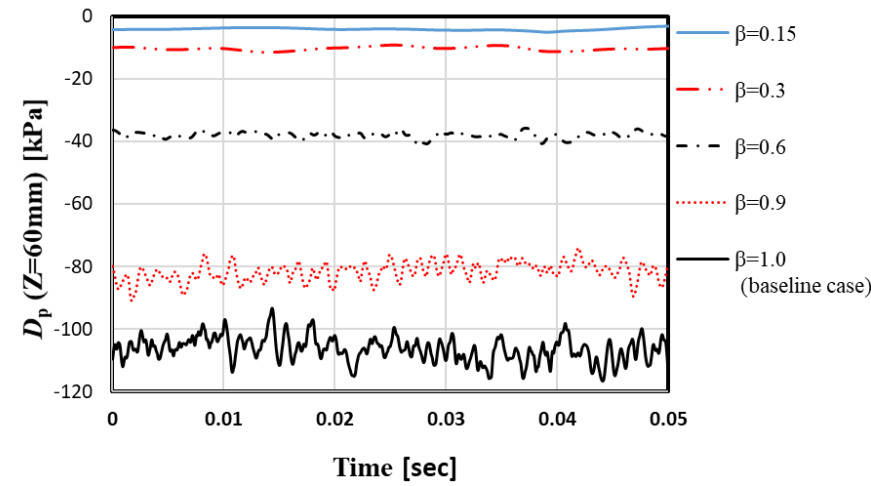

Fig. 18 Time series of static pressure at center of computational domain at a height of $Z=60 \mathrm{~mm}$ in base line case and Case $\mathrm{D}$.

(1) 定常な渦になる条件

$\alpha \leqq 0.4$ （スワール数Sが 0.65 以下）の条件では流れ場はほぼ定常の状態を維持しており，自由渦および強制渦 で構成されるランキン渦が形成されるが， $\alpha$ の増加に伴い渦コアの半径は徐々に小さくなる. 理論解である Burgers渦は定常かつ軸方向速度が半径方向に一様であることが仮定されるが，図15（b-1）に示すとおり， $\alpha$ の増加とともに渦コア（半径 $2 \mathrm{~mm}$ 以下）において軸方向速度が増大し， $\alpha=0.4$ では渦中心近傍の軸方向速度 は渦の外側の軸方向速度の 2.6 倍に達している. このため, 渦の伸長が大きくなり, 渦コアの半径が小さくな

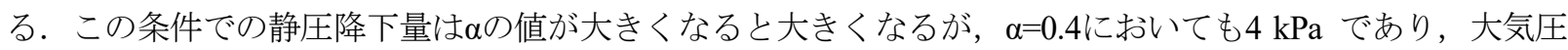
の約4\%である.

(2) 渦が乱流遷移寸る条件

$\alpha$ の值が0.4（スワール数Sが0.65）を超えると渦の状態が定常の渦から非定常的に振れ回る渦に変化する. 渦 コア半径における周方向速度，および圧力の周波数スペクトルを調べたところ，この条件で渦は乱流に遷移 していることがわかった．渦の振れ回りが始まると，渦コアは軸方向にも伸び縮みをするようになる．渦が 乱流に遷移する臨界レイノルズ数は，前記のように流入境界で与えた渦コア半径，および，そこでの周方向 速度を基準にして $3.5 \times 10^{3}$ であった． $\alpha \leqq 0.4 の$ 条件では，周方向速度の分布は，中心近傍は強制渦，その外側 では自由渦の分布となっているランキン渦に近い分布をしており, 強制渦の分布と自由渦の分布が接続する

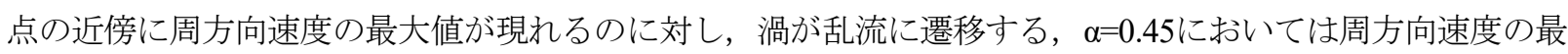
大值が現れる点が渦の中心に向かって大きく移動し, 渦コアの半径が $1.5 \mathrm{~mm}$ から $0.5 \mathrm{~mm}$ と急に小さくなる. そのため, 周方向速度の分布はランキン渦の分布とは大きく異なる. 周方向速度分布がランキン渦の分布を 保ったまま伸長したと仮定した場合よりも渦コアの周方向速度が小さくなる理由は, 渦の振れ回りや軸方向 の伸び縮みにより散逸量が急激に増大寸るための推定される. 渦コアの急激な縮小に伴い, 渦中心の静圧降 下量は $3.4 \mathrm{kPa} ら 6.2 \mathrm{kPa}$ と 1.8 倍に急増する. さらに $\alpha$ の值を大きくする $(\alpha=0.5,0.6)$ と渦コアの半径はあ まり変化しないが, 流入境界の最大周方向速度 $C_{\mathrm{u} 0}$ で規格化した周方向速度は $1.8 \quad(\alpha=0.45)$ から $2.9(\alpha=0.6)$ に増加する. 一方, 軸方向速度の分布は $\alpha=0.45$ までは渦の中心で最大值をとるが，それよりも大きな $\alpha$ の值で

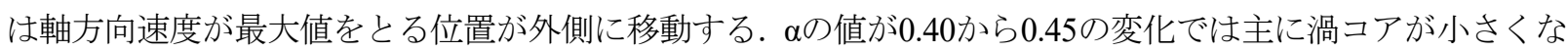
ることにより静圧が降下しており，一方， $\alpha$ の值が 0.45 から $0.6 に$ 変化する範囲では，渦コア半径はあまり変 わらないが同じ半径で周方向速度が増大したことにより渦の中心の静圧は降下寸る.

(3) 渦が平衡状態にある条件

$0.65 \leqq \alpha \leqq 0.85$ の（スワール数Sが $1.06 か ら 1.39 ）$ 範囲では， $\alpha$ の值が大きくなると渦中心の静圧降下量の絶対 值は大きくなるが，流入境界で与えた最大周方向速度 $C_{\mathrm{u} 0}$ で無次元化した周方向速度分布は $\alpha$ の值によらずほ

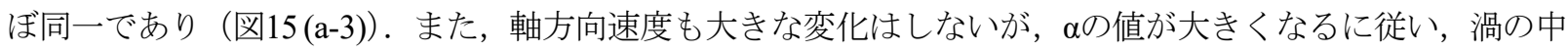
心近傍の軸方向速度が小さくなる. 遠心力により渦コアが拡大しようとする効果と軸方向の加速により渦が 伸長する効果が均衡しており, 周方向速度の分布が変化しないものと推定される. 
(4) 渦コアが拡大寸る条件

ベースラインケース（ $\alpha=1.0 ）$ を含む $1.0 \leqq \alpha \leqq 1.5$ （スワール数 $\mathrm{S}$ が1.63から2.45）の範囲では， $\alpha$ の值が大きく なると渦中心の静圧降下量は大きくなるが，その変化は小さく, 流入境界で与えた最大周方向速度で無次元 化した渦中心の静圧降下量は $\alpha$ の值が大きくなると小さくなる．渦コアの半径も流入境界における值（3.0 $\mathrm{mm}$ ）よりも小さくなるが， $\alpha$ 值が大きくなるに従い，高さ $60 \mathrm{~mm}$ の断面における渦コアの半径は大きくな

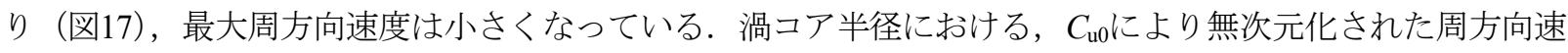

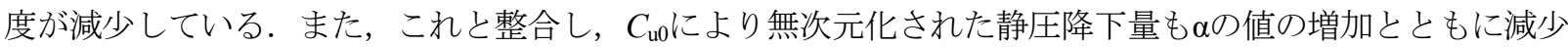
寸る (図16(b-4))．この理由は $\alpha$ の值の増加により，渦の振れ回りが大きくなり，周方向速度が最大值をとる 位置が渦の中心から離れた位置に移動したためと考えられる.この範囲の $\alpha$ の值では周方向速度の分布の形 は $\alpha$ の值が0.4以下の場合に現れたランキン渦の分布に再び近づいていく.

前節に示したケース A において, ベースラインケースに対し格子解像度をあげた場合の静圧降下量は逆に小さ くなった（ベースラインケースでは $106.4 \mathrm{kPa} ， 2$ 倍，4 倍の格子解像度を用いたケースではそれぞれ $99.9 \mathrm{kPa}$, $96.9 \mathrm{kPa})$ ．この理由として，解像度をあげると，上述した渦の触れ回りによる渦の拡大効果がより正確に捉えら れ, 結果として振れ回りが大きくなり, 静圧降下量が減少したものと推察される. 格子解像度と渦の触れ回り効 果の調査については今後の課題であるが，本研究ではベースラインケースの条件，あるいはそれよりも高解像度 の条件で静圧降下量はほぼ $100 \mathrm{kPa}$ に達しており, 数值計算により渦コアの静圧が飽和蒸気圧以下になることを 確認できた。

\section{(4) 軸方向加速度の強さと水中渦の成長との関係}

既報（山出他，2019）で実施した水槽モデルを対象とした LES 解析では，高さ $100 \mathrm{~mm}$ におけるべルマウス入 口における軸方向速度の平均值は約 $2.0 \mathrm{~m} / \mathrm{s}$ であり, 簡易モデルの領域で一定の加速度を仮定すれば, 本簡易モデ ルの流入面である高さ $30 \mathrm{~mm}$ の断面における軸方向速度の平均值はベルマウス入口における軸方向速度の平均 值の $30 \%$ ，すなわち $0.6 \mathrm{~m} / \mathrm{s}$ であり，ベースラインケースで流入境界に与えた軸方向速度と整合する. しかしなが ら，水槽を対象とする LES 解析における，水中渦発生時の軸方向速度の分布（図 3 (b)）では渦の外側で $0.1 \mathrm{~m} / \mathrm{s}$ 程度しかないため, 半径 $30 \mathrm{~mm}$ の流入境界面全体に $0.6 \mathrm{~m} / \mathrm{s}$ の軸方向速度を与えるベースラインケースの条件は 過大な軸流速度を与えている可能性がある。 そこで，本節では流入境界で与える軸方向速度の大きさと渦の成長 との関係を調查するため, 軸方向速度の比 $\beta \equiv C_{z 0} / C_{\text {zo_base }}$ を 0.15 から 2.2 （1.0 はベースラインケースに相当） まで変化させた計算を実施した。ここで $C_{z_{-} \text {base }}$ はベースラインケースで流入境界に与えた軸方向速度 $(0.6 \mathrm{~m} / \mathrm{s})$ であり，また， $C_{z 0}$ は各ケースで流入境界に与えた軸方向速度である。この計算では流入境界で与えた最大周方向 速度はベースラインケースと同じ值としたため $\left(C_{\mathrm{u} 0}=C_{\mathrm{u} 0 \text { base }}=2.94 \mathrm{~m} / \mathrm{s}\right)$, 式 (9) により定義されるレイノルズ数 は一定 $(8,820)$ である. 一方, $\beta$ の值が 0.15 から 2.2 まで変化する際, スワール数 $\mathrm{S}$ は 10.89 から 0.74 まで変化 する. 前述のとおり, ベースラインケースの $C_{z 0}$ は過大である可能性があるため, 本節ではが 1 以下のケース, すなわち，スワール数 S がベースラインケース以上になる場合の結果のみを示す． $\beta$ が 1 より大きい場合（スワ 一ル数がベースラインケースよりも小さくなる場合) の計算結果については次節にて説明する. 図 18 に高さ $60 \mathrm{~mm}$

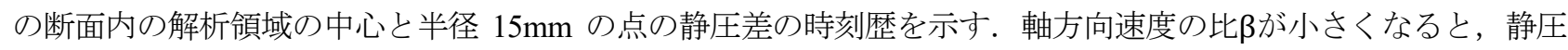
効果量が急激に減少する. 軸方向の速度比 $\beta=0.3$ の場合の静圧降下量は $10.3 \mathrm{kPa}$ であり, ベースラインケースの 静圧降下量 $106.4 \mathrm{kPa}$ に対し約 $1 / 10$ に減少する.この理由に関しては次節にて説明する.

\section{(5) スワール数と吸込渦の成長との関係}

本研究では, Case C においてベースラインケースの值を中心として, スワール数 $\mathrm{S}$ とレイノルズ数を同時に変 化させ，一方，Case D においてはレイノルズ数を一定にしてスワール数 S のみを変化させ，吸込渦の挙動を調査 した.これらのケースで調査したスワール数とレイノルズ数を示寸と図 19 の左図のようになる. Case C の結果 と Case D の結果を改めてスワール数により整理すると図 19 の右図のようになる. 流入境界で与えた周方向速度 の最大值で規格化した圧力降下に関して, Case C の結果と Case D の結果は一つの曲線上に乗っている.このこ とは, 本研究で調査したレイノルズ数の範囲においては, 水中渦の挙動はレイノルズ数には依らず, 専らスワー 
ル数により決まることを示唆している. 特に，スワール数 S の值が 0.8 から 2 のとき，水中渦はその成長過程で 乱流遷移し，それに伴い，渦コアの静圧が急激に低下寸る. 本研究が対象とした水中渦や童巻，台風などは上向 きの加速流の中で渦のストレッチされることにより発生する。これらの発生を予測することの本質的な難しさは 図 19 の右側に示したように，これらの渦は比較的狭い範囲のスワール数の条件になった時に限って成長するこ とに起因しているものと思われる.
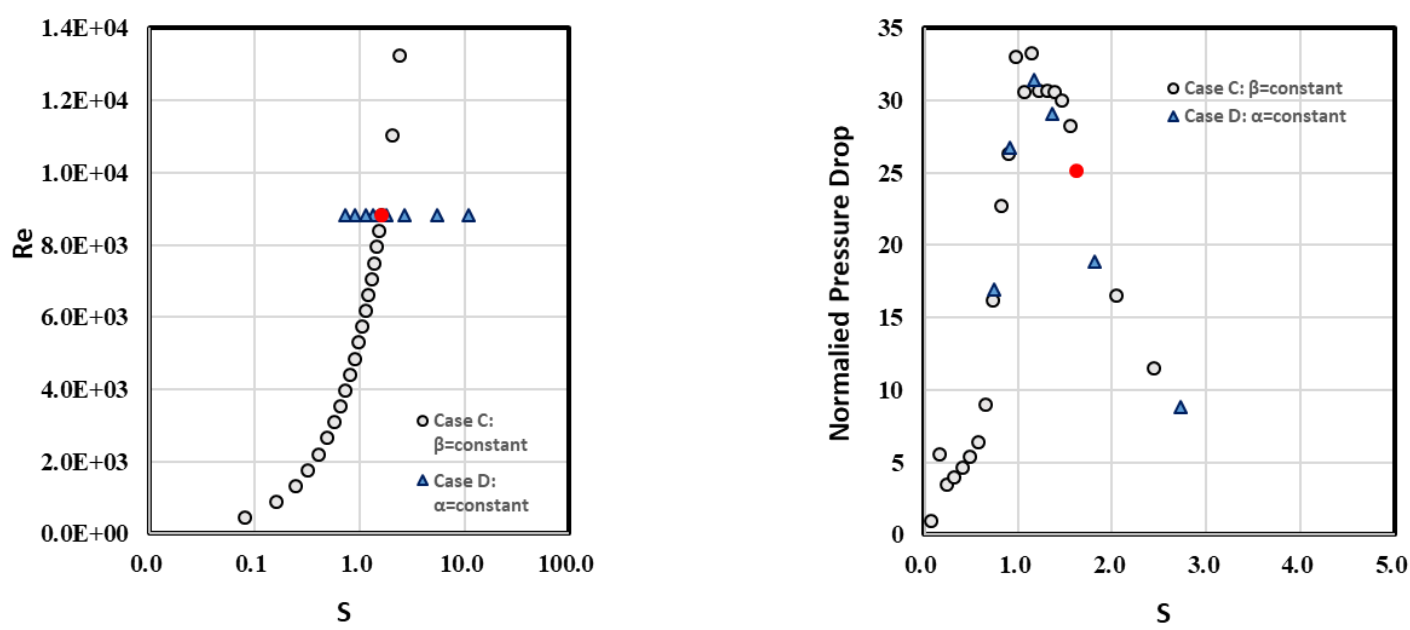

Fig. 19 Swirl numbers and Reynolds numbers studied in Case C and Case D (left) and normalized pressure drop plotted against the swirl numbers (right) for these cases. Marks in red indicate baseline case.

\section{7. 結 言}

モデル水槽に発生する水中渦に関して, 渦のコア領域における静圧降下量も含めて定量的な予測を実現するこ とを目的とし，モデル水槽におけるポンプ配管下の加速流れを模擬した簡易形状の解析モデル内の流れを対象に 解析格子の解像度, 解析の時間刻み, および流入境界において与えた旋回の強さや軸方向の速度を種々変化させ たLES解析を実施した。本研究により得られた主要な結論は以下にとおりである.

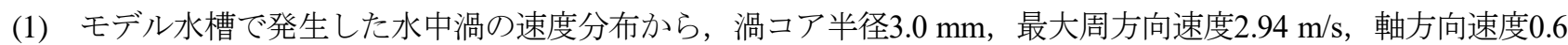
$\mathrm{m} / \mathrm{s}$ を流入境界条件として与えた，格子解像度 $15 \mu \mathrm{m}$ のLES解析を実施したところ，渦中心の静圧は常温にお ける飽和水蒸気圧以下に低下し，キャビテーションが発生する条件を再現できることを確認した.

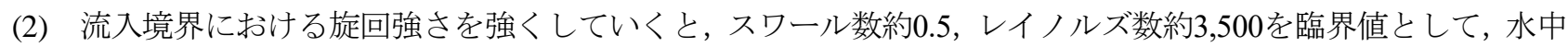
渦は振れ回りを始め, 渦は乱流遷移する.さらに旋回を強くしていくと, スワール数約1.3から1.8の範囲で遠 心力による渦コアの拡大と渦の伸長による渦コアの縮小が均衡し, 周方向速度分布が変化しなくなる.さら に旋回を強くしていくと，渦が拡大しようとする効果が卓越し，渦の中心における，流入境界で与えた周方 向速度の最大值で無次元化された静圧降下量は逆に小さくなる. 水中渦の非定常性が強くなり, 渦コアの静 圧が大きく降下寸るスワール数の範囲はおよそ $0.8 か ら 2$ 程度であり，このような条件が成立したときに限っ て, 強い水中渦が発生する.

(3) 渦が拡大しようとする効果が卓越するスワール数の範囲において, 渦コアは振れ回り運動に加えて, 渦の軸 方向に伸び縮み寸るようになり，この現象を捉えるのに十分小さな時間刻みで数值解析を行う必要がある.

\section{謝 辞}

本研究成果（の一部）は，理化学研究所のスーパーコンピュータ「京」を利用して得られたものである（課題 番号 : hp180190)。ここに記して関連各位に謝意を表する. 


\section{文献}

Ansar, M. and Nakato, T., Experimental study of 3d pump-intake flows with and without cross flow, Journal of Hydraulic Engineering, Vol. 127, No. 10 (2001), pp. 825-834.

Ansar, M., Nakato, T. and Constantinescu, G. S., Numerical simulations of inviscid three-dimensional flows at single- and dual-pump intakes, Journal of Hydraulic Research, Vol. 40, No.4 (2002), pp. 461-470.

Burgers, J. M., A mathematical model illustrating the theory of turbulence, Advances in Applied Mechanics, Vol. 1 (1948), pp. 171-199.

Constantinescu, G. S. and Patel, V. C., Role of turbulence model in prediction of pump-bay vortices, Journal of Hydraulic Engineering, Vol. 126, No. 5 (2000), pp. 387-391.

Germano, M., Piomelli, U., Moin, P. and Cabot, W. H., A dynamic subgrid-scale eddy-viscosity model, Physics of Fluids A, Vol. 3, No. 7 (1991), pp. 1760-1765.

Kato, C., Kaiho, M. and Manabe, A., An overset finite-element large-eddy-simulation method with application to turbomachinery and aeroacoustics, Transactions of ASME, Journal of Applied Mechanics, Vol. 70 (2003), pp. $32-43$.

Kato, C., Yamade, Y., Wang, H., Guo, Y., Miyazawa, M., Takaishi, T. and Takano, Y., Numerical prediction of sound generated from flows with a low Mach number, Computers \& Fluids, Vol. 36, No. 1 (2005), pp. 53-68.

Lilly, D. K., A proposed modification of the Germano subgrid-scale closure model, Physics of Fluids A, Vol. 4, No. 3 (1992), pp. 633-635.

Okamura, T., Kamemoto, K. and Matsui, J., CFD prediction and modeling experiment of suction vortices in pump sump, Proceeding of the 9th Asian International Conference on Fluid Machinery (2007), Paper No. AICFM9-053.

山出吉伸, 加藤千幸, 長原 孝英, 松井純, ポンプ吸込水槽における吸込渦発生メカニズム, 日本機械学会論文 集，Vol. 85, No. 875 (2019), DOI: 10.1299/transjsme.19-00072.

吉村忍, 徳永健一, 杉本振一郎, 奥田洋司, 末光啓二, 加藤千幸, 山出吉伸, 吉村英人, 並列モデル細分化による 大規模有限要素解析の効率化，日本計算工学会論文集 (2013), Paper No. 20130012.

\section{References}

Ansar, M. and Nakato, T., Experimental study of 3d pump-intake flows with and without cross flow, Journal of Hydraulic Engineering, Vol. 127, No. 10 (2001), pp. 825-834.

Ansar, M., Nakato, T. and Constantinescu, G. S., Numerical simulations of inviscid three-dimensional flows at single- and dual-pump intakes, Journal of Hydraulic Research, Vol. 40, No.4 (2002), pp. 461-470.

Burgers, J. M., A mathematical model illustrating the theory of turbulence, Advances in Applied Mechanics, Vol. 1 (1948), pp. 171-199.

Constantinescu, G. S. and Patel, V. C., Role of turbulence model in prediction of pump-bay vortices, Journal of Hydraulic Engineering, Vol. 126, No. 5 (2000), pp. 387-391.

Germano, M., Piomelli, U., Moin, P. and Cabot, W. H., A dynamic subgrid-scale eddy-viscosity model, Physics of Fluids A, Vol. 3, No. 7 (1991), pp. 1760-1765.

Kato, C., Kaiho, M. and Manabe, A., An overset finite-element large-eddy-simulation method with application to turbomachinery and aeroacoustics, Transactions of ASME, Journal of Applied Mechanics, Vol. 70 (2003), pp. $32-43$.

Kato, C., Yamade, Y., Wang, H., Guo, Y., Miyazawa, M., Takaishi, T. and Takano, Y., Numerical prediction of sound generated from flows with a low Mach number, Computers \& Fluids, Vol. 36, No. 1 (2005), pp. 53-68.

Lilly, D. K., A proposed modification of the Germano subgrid-scale closure model, Physics of Fluids A, Vol. 4, No. 3 (1992), pp. 633-635.

Okamura, T., Kamemoto, K. and Matsui, J., CFD prediction and modeling experiment of suction vortices in pump sump, Proceeding of the 9th Asian International Conference on Fluid Machinery (2007), Paper No. AICFM9-053.

Yamade, Y., Kato, C., Nagahara, T. and Matsui, J., Formation mechanism of suction vortices in a pump sump, Transactions of the JSME (in Japanese), Vol. 85, No. 875 (2019), DOI: 10.1299/transjsme.19-00072.

Yoshimura, S., Tokunaga, K., Sugimoto, S., Okuda, H., Suemitsu, K., Kato, C., Yamade, Y. and Yoshimura, H., Efficient large scale finite element analyses with parallel model refinement, Transactions of JSCES (2013), Paper No. 20130012 (in Japanese). 